\title{
La legislación laica desbordada. El anticlericalismo durante la segunda república
}

\author{
juan Manuel Barrios Rozúa
}

\begin{abstract}
RESUMEN
Suele afirmarse que la política de los gobiernos republicano-socialistas hacia la Iglesia fue de una gran torpeza al desatar un conflicto que la debilitó. Partiendo del estudio de dos diócesis, las de Guadix-Baza y Granada, éste articulo trata de refutar esa opinión tan extendida. No fue tanto el anticlericalismo de muchos de los ministros y políticos más destacados de la izquierda, como la gran presión popular a la que estaban sometidos, la que determinó la adopción de medidas

laicizadoras en un intento, finalmente fallido, de encauzar el choque cotidiano y muchas veces violento de las clases populares con una Iglesia alineada con las derechas.
\end{abstract}

PALABRAS CLAVE Segunda República, anticlericalismo, Iglesia, movimiento obrero, patrimonio histórico.

\section{ABSTRACT}

Tend be affirmed that the policy of the republican-socialistic governments toward the Church was of a great turpitude upon unleashing a conflict that weakened it. Departing of the study of two diocese, those of GuadixBaza and Granada, this article tries of refuting that opinion so extended. It was not the anticlericalism of many of the ministers and political more outstanding of the left, as well as the great popular pressure to the one which were submitted, the one which determined the lay decision-making in an intent, finally insolvent, of channeling the daily shock and many violent times of the popular classes with a Church aligned with the rights.

\section{KEY WORDS}

Second Republic, anticlericalism, Church, worker movement, historical patrimony. 


\section{LA DESCRISTIANIZACIÓN AL COMIENZO DE LA SEGUNDA REPÚBLICA}

En buena parte de España los párrocos constataban cotidianamente la dramática reducción que había sufrido la comunidad católica desde el primer tercio del siglo anterior, cuando el Antiguo Régimen naufragó y dio paso al liberalismo. Medio siglo de Restauración alfonsina había propiciado un renacer del clero regular y extendido la influencia de la Iglesia, pero la hostilidad de una parte importante de la población y la indiferencia de otra, mostraban los estrechos límites del renacer eclesiástico. La proliferación de conventos, la multiplicación de propiedades del clero y la influencia de la Iglesia sobre el Estado, tenían como contrapartida los bajos indices de asistencia al culto y el activo anticlericalismo de la izquierda.

La afirmación de Azaña de que España había dejado de ser católica sembró la indignación de los medios conservadores y de la prensa católica ${ }^{1}$, pero más allá de la negativa de la jerarquía eclesiástica a aceptar la realidad, el párroco de a pie constataba día a día el grado de descristianización de su feligresía. Muy pegados al terreno, estos sacerdotes no podian engañarse a si mismos, y tampoco ocultaban la realidad a los obispos cuando éstos les pedían información ${ }^{2}$. Otra cosa es como explicaran los motivos que habían llevado a este estado de cosas y cuáles eran los remedios para alcanzar la total recristianización del país. Un párroco de Montefrío describía así la situación en la que se encontraba su localidad:

"Los habitantes de Montefrío, en tiempos no muy lejanos, fueron buenos católicos. Desde comienzos del presente siglo la fé se ha venido debilitando $y$ arrancando de muchas almas, por las propagandas atheas y marxistas que se acentuaron, aquí en esta villa, más que en ningún otro pueblo de la provincia. Los barrios obreros de la población estaban totalmente infestados de socialismo. La fé y las buenas costumbres desterrados de muchos hoga-

Quien mejor ha estudiado el alcance y significado, tantas veces tergiversado por la derecha, de la frase de Azaña ha sido Raguer, H. «"España ha dejado de ser católica" la politica religiosa de Azaña", Historia Contemporánea, 6 (1991), pp. 146-147.

2 Cosa bien diferente es que lo que la jerarquía eclesiástica quisiera creer. Un informe elaborado por los sacerdotes Lluís Carreras y Antoni Vilaplana el 1 de noviembre de 1931 señalaba: "El oficialismo católico de España durante la monarquía, a cambio de innegables ventajas para la Iglesia, impedía ver la realidad religiosa del pais y daba a los dirigentes de la vida social católica, y a los católicos en general, la sensación de hallarse en plena posesión de la mayoría efectiva". Pero la realidad era bien diferente: «La falta de religiosidad cristiana entre las elites, el alejamiento de las masas, la carencia de una verdadera estructura de instituciones militantes, el escaso influjo de la mentalidad cristiana en la vida pública eran signos que no permitian una confianza firme". Citado por Raguer, H., La Espada y la Cruz (la Iglesia, 1936-1939), Barcelona, Bruguera, 1977 , pp. 16 y 17. 
res, hacia que gran parte de los feligreses vivieran en torpe concubinato; que muchos niños no recibieran el bautismo y muy pocos [...] cumplieran con el precepto de oír la Santa Misa los días festivos y [de] cumplimiento pascuals ${ }^{3}$.

Otro testimonio más autocrítico con el papel desempeñado por la Iglesia en el pasado era el del cura regente de Zagra, quien tras señalar la pobreza de sus habitantes, añade:

"Pero si el abandono material y moral-psicológico es grandísimo no lo es menos en el orden religioso, incluso por las mismas causas, y por la conducta exageradamente censurable de varios y seguidos señores curas párrocos que han dado escándalos grandísimos, dando con ello ocasión a la gran indiferencia religiosa, ignorancia en cultura religiosa, nula práctica en la piedad y culto católico. En esta situación moral-psicológica y religiosa llegó Zagra cuando la proclamación de la República española el año 1931" 4 .

El cura de Pinos Puente demostraba con datos contundentes el grado de descristianización que había alcanzado su pueblo. De las aproximadamente 10.000 personas que residian en la localidad, sólo 20 hombres y 200 mujeres iban a la misa dominical antes de la República. Meses después de la proclamación de ésta las cifras habian descendido a 10 y 40 respectivamente, con el agravante de que sólo una pequeña minoría de éstos comulgaba los domingos. El párroco reconocia que la mayoría del pueblo era muy poco religiosa desde antiguo y que estaba fuertemente penetrada por las doctrinas izquierdistas. Este hecho lo explicaba el sacerdote por

"La conducta totalmente irreligiosa de muchos ricos, y tal vez más aún la de aquellos patronos que llamándose católicos no procuraron el bien espiritual y material de sus obreros, desprestigiando asi y haciendo odiosa ante el pueblo la religión que decian profesar" 5 .

La identificación del catolicismo con las derechas y las clases acomodadas, tal y como constatan los curas de Zagra y Pinos Puente, constituye

\footnotetext{
Informe del arcipreste Manuel P. fechado el 20 noviembre 1939. Archivo de la Diócesis de Granada (ADG), 190-F/96.

Informe de Victoriano G. fechado el 6 diciembre 1939, ADG, 190-F/144.

Antes de la República sólo comulgaban 5 hombres y 20 mujeres. Tras la proclamación de ésta la cifra fue disminuyendo hasta quedar en 2 hombres y 6 mujeres. El grado de asistencia a la misa dominical tras el golpe de Estado de 1936 no iba a mejorar mucho, teniendo en cuenta las circunstancias: 40 hombres y 300 mujeres. Informe de Toribio Molina fechado el 6 junio 1938 , ADG, $190-F / 116$.
} 
el factor más importantes a tener en cuenta para comprender el hondo anticlericalismo que se detecta en las provincias de Granada y Almeria. Otro de los factores apuntados en los testimonios, la conducta inmoral de algunos clérigos, hay que englobarlo dentro de las deficiencias que arrastra desde antiguo el clero secular. Los problemas del clero no se limitaban sólo a conductas censurables - achacables sólo a una minoria, aunque tenían un fuerte impacto sobre la imaginación popular-, sino que se manifestaban también en una deficiente formación y en un desigual reparto geográfico que dejaba barrios o comarcas pobres muy desatendidos en lo espiritual ${ }^{6}$.

Andalucía y las demás provincias meridionales mostraban el lado más dramático de la descristianización. Pese a que el sur peninsular encontraba su contrapeso en territorios de fuerte tradición católica como Castilla la Vieja o el País Vasco, el panorama resultaba en general poco consolador para el clero. Gerald Brenan calculaba que «no más del 20 por ciento de los habitantes de España eran católicos practicantes" ${ }^{7}$. Su opinión estaba muy marcada por los datos pesimistas que el padre Francisco Peiró dio a conocer en 1931, unos datos que todo parece indicar no andaban muy distantes de la realidad ${ }^{8}$.

\section{DERECHA E IGLESIA CONTRA LA REPÚBLICA}

\section{La causa común de la Iglesia y las derechas}

Las reticencias de la jerarquía eclesiástica ante la proclamación de la República y el caso del cardenal Segura constituyen acontecimientos objeto de interminables controversias e interpretaciones historiográficas. Se ha resaltado desde perspectivas conciliadoras o abiertamente proeclesiásticas que la Iglesia acató el nuevo régimen, pese a no verlo con los mejores ojos, y que las autoridades republicanas se mostraron en exceso suspicaces o prepotentes. Pero analizar la rápida transición política y el temprano choque entre el Estado republicano y la Iglesia a partir de lo acaecido en las "altas esferas» es cuanto menos empobrecedor.

6 Los problemas del clero, y el surgimiento y desarrollo del anticlericalismo en Granada los he estudiado con detalle en BARRIOS RozUA, J. M., Reforma urbana y destrucción del patrimonio histórico. Ciudad y desamortización, Editorial Universidad de Granada y Junta de Andalucía, 1998.

Brenan, G., El laberinto español, Madrid, Globus, 1983, p. 260.

* Escribe Brenan que según alos datos del padre Francisco Peiró, sólo el 5 por 100 de los campesinos de Castilla la Nueva y de toda la España central iban a misa y atendian al cumplimiento pascual; en Andalucía la asistencia de los hombres a las ceremonias religiosas era de un 1 por 100. En Madrid, la situación no era más favorable a la Iglesia [...]”. BrenAN, op. cit., p. 260. 
Pese a la actitud prudente adoptada en principio por buena parte de la jerarquía eclesiástica española y del Vaticano ${ }^{9}$, el clero vivió el fin de la monarquía borbónica como un desastre. La protección y privilegios que le habían ofrecido los gobiernos de la Restauración y de la Dictadura iban a verse recortados tras el giro republicano. Eso era evidente tanto para los miembros del alto clero como para los del bajo.

No era necesario, por otra parte, que un gobierno republicano de izquierdas adoptase medidas anticlericales para que la derecha y la Iglesia se aliaran. Esta alianza era previa y no constituía un pacto defensivo contra las "agresiones» de la izquierda, sino una simbiosis de dilatada gestación. Respetar los privilegios de la Iglesia, algo imposible dada la fuerte presión a la que estaba sometido el gobierno por su izquierda, podría haber deparado una actitud más diplomática por parte de la jerarquía, pero la inmensa mayoría del clero habría continuado respaldando la vuelta de las derechas más allá de apariencias formales. No podemos olvidar que la actitud de la Iglesia desde el comienzo de la Restauración alfonsina no había sido la mera defensa de sus intereses frente a posibles recortes, sino el aumento de su influencia en todos los campos. Durante la propia Dictadura de Primo de Rivera el catolicismo había experimentado avances notables en un campo tan relevante como la educación. La Iglesia estaba, pues, a la ofensiva bajo el lema de que España y el catolicismo eran inseparables; la indiferencia a las prácticas religiosas que mostraba la mayoria de la población y la franca hostilidad de una parte importante de ésta no eran reconocidas oficialmente. Esta actitud proselitista e integrista sólo podía deparar un enfrentamiento ahora que la izquierda, después de cincuenta y ocho años de marginación y represión, iba a tener la posibilidad de dar salida a los anhelos y reivindicaciones largamente contenidos de una parte de la ciudadanía.

¿Qué podía considerar el clero como una medida persecutoria? Cabe imaginar que como tales sólo serían valoradas decisiones como la expulsión de los jesuitas o el cierre de colegios confesionales. Sin embargo, cualquier actitud oficial o popular que se alejara de los cánones de conducta establecidos por la Iglesia merecía el calificativo de persecución. La separación de Iglesia y Estado o la ley del divorcio eran medidas

9 Es oportuna la observación de Jackson: «Los obispos aconsejaron la obediencia a las autoridades establecidas, sí, pero asimismo justificaron el que no se las reconociera, basándose en que el Gobierno se llamaba a sí mismo "provisionał" y que el rey se había limitado a ausentarse de España, sin abdicar». JACkson, G., La República española y la Guerra Civil, México, Editora Americana, 1967, p. 38 
persecutorias ${ }^{10}$. Como "fobia antirreligiosa" y clima de persecución se valoraban los entierros laicos, los matrimonios civiles o el que no se bautizara a un niño ${ }^{11}$. Para el clero los españoles no tenian más opción que ser católicos o vivir como tales.

El retorno de las derechas al poder constituía la única vía posible para continuar con el peculiar proceso de recristianización de España puesto en marcha con la Restauración. Pero estas simpatías hacia la derecha iban más allá de una mera alianza táctica. La Iglesia española se identificaba abiertamente con los valores de las clases acomodadas y vinculaba estrechamente el cuestionamiento de la propiedad con el del catolicismo. El cura de Asquerosa se mostraba consternado ante los mítines que se celebraban durante la República en el pueblo porque

“estaban saturados de doctrinas disolventes y marxistas por lo que era frecuente oír que los frutos que habian producido con el sudor de su frente y las tierras que trabajaban, les pertenecían, que eran suyas y no de los propietarios. [Y añade que tales] predicaciones como era lógico llegaron a producir sus frutos creando una situación violenta en contra de la Iglesia y de persecución a la persona del párroco" ${ }^{12}$.

El catolicismo jugará un papel decisivo en la aglutinación de las derechas, divididas y desconcertadas tras la caída de la monarquía. No habrá ningún nexo de unión mejor que la defensa de la Iglesia entre los monárquicos, los accidentalistas y los carlistas; hasta el propio fascismo español será una excepción al distanciarse del anticlericalismo de los movimientos italiano y alemán ${ }^{13}$. El principal partido de derechas, Acción Nacional, luego rebautizado como Acción Popular, tendrá como principios básicos: «Religión, Patria, Orden, Familia, Propiedad» ${ }^{14}$.

10 «La doctrina oficial de la Iglesia continuaba propugnando, casi como dogma de fe, el principio del Estado confesional", a la par que algunos eclesiásticos inculcaron a los católicos "una mentalidad de Iglesia perseguida" RAGUER, H., "La cuestión religiosa", Ayer, 20 (1995), pp. 222 y 235.

"Según el informe del párroco de Zagra: «Durante los años republicanos que precedieron al Glorioso Movimiento Nacional, este pueblo, ya bastante indiferente en materia de religión [...] se distinguió por su fobia antirreligiosa, comprobada por los numerosos entierros laicos, matrimonios civiles, es decir, concubinatos públicos, incuria por parte de los padres en el bautismo de sus hijos, falta absoluta y desprecio de la piedad y un reinado de blasfemias y persecución sorda contra la religión cristiana y sus ministros. El sacerdote como tal molestaba a la mayoría [...]". Testimonio del sacerdote Victoriano G., ADG, 190-F/144.

12 Testimonio fechado el 2 de junio de 1938. ADG, 190-F/20.

13 RoDRiguez Jiménez, J. L., La extrema derecha española en el siglo XX, Madrid, Alianza, 1997, p. 148.

14 ROdRIGUEZ JIMÉNEZ, op. cit., p. 111. 
Estos serán también los principios del ldeal, periódico propiedad de la Iglesia que jugará un papel decisivo en la provincia de Granada en la conformación, cohesión y movilización de la derecha granadina. Utilizando como corresponsales a los párrocos, este periódico denunciará diariamente toda clase de "abusos" cometidos por los trabajadores y la legislación republicana contra los propietarios. El mismo énfasis pondrá en la denuncia de todo signo de "persecución" contra la Iglesia. Más tarde mostrará sus simpatías por los regímenes fascistas de Italia y Alemania, y alentará una intervención autoritaria que «restaure el orden». La miseria en que vive buena parte de la población rural o las difíciles condiciones de vida de las clases populares en la ciudad de Granada serán problemas que apenas encuentren un hueco en las páginas del diario. El único sindicalismo que desfile por sus páginas será el católico, absolutamente marginal en la provincia ${ }^{15}$.

El discurso del periódico católico coincidirá punto por punto con la ideología exhibida por las derechas en sus campañas políticas: defensa de la propiedad, vagas propuestas de justicia social apoyadas en la doctrina cristiana, denuncia del "desorden público», unidad y grandeza de España, cuestionamiento de los valores democráticos... Dificilmente podía indicarse dónde empezaba la doctrina oficial de la Iglesia y dónde la retórica de las derechas, particularmente de Acción Popular y su coalición la CEDA. Por ello las afirmaciones esgrimidas de tiempo en tiempo desde medios conservadores sobre la neutralidad del clero no podían engañar a nadie. Un presbítero republicano, Juan García Morales, denunciaba con contundencia este tipo de argumentaciones:

«El señor Gil Robles, agotados los argumentos, ha tenido el valor de decir, contestando a don Miguel Maura, que el clero español no es político, ni se mezcla para nada en la política; que el clero, abrazado a la luz de Jesucristo, y siguiendo las huellas del divino maestro, sólo se dedica a derramar por el mundo la luz del Evangelio.

«... Verdad debía de ser, y otro gallo nos cantara; pero no es asi. El clero español, salvo raras excepciones, lleva en su sangre la polilla de la política.

"¿Conque el clero no es político? ¿Conque el clero no se mezcla en política? Entonces... ¿Por qué los curas recomiendan que se vote a la candidatura de las derechas? ¿Por qué los sacerdotes, en corrillos y tertulias,

15 Gerald Brenan, que tan de cerca conoció la Granada de la República, definió justamente el papel del sindicalismo católico: "Los patronos, que proporcionaban el dinero y daban trabajo a los parados, esperaban en compensación utilizar las asociaciones católicas para romper las huelgas. Cosa que a los trabajadores les repugnaba hacer. $Y$ asi sucedió que al cabo de años de trabajo y esfuerzos en medio de grandes dificultades, las asociaciones católicas se vieron obligadas a admitir su completo fracaso, salvo ciertas regiones del Norte [...]". BRENAN, op. cit., p. 83 
ponen sobre los cuernos de la luna a Acción Popular y pregonan a los cuatro vientos que este partido será el único que salvará a España? ¿Por qué ese afán de propagar por todas partes la lectura de "El Debate», del "ABC" y de otros periódicos derechistas, $y$ ese odio y encono con los adversarios $\gg 16$.

Aunque el catolicismo servirá de aglutinante a las derechas, la "persecución" no será una problema fundamental para éstas. El problema esencial era la cuestión socioeconómica, o sea, las concesiones que habían de hacer a las clases populares y el miedo a que la situación desembocara en una revolución. El asunto religioso era más una coartada ideológica que una causa de fondo ${ }^{17}$. En realidad, el choque entre laicismo e Iglesia era muchas veces una continuación en el campo ideológico del enfrentamiento de clases que se libraba por la mejora de las condiciones de vida de los asalariados ${ }^{18}$. Buena parte de los sucesos anticlericales serán derivaciones violentas de huelgas, mítines obreros o movilizaciones antifascistas. Si señaláramos en un mapa de la provincia los lugares con más episodios anticlericales, estos coincidirian en líneas generales con las zonas más conflictivas socialmente por su elevado porcentaje de obreros y jornaleros, o sea, la capital y su entorno, la costa y los grandes pueblos en general. Por el contrario, las Alpujarras, con sus numerosas y reducidas poblaciones en las que abundan los pequeños propietarios agrícolas se muestran como las localidades con menos tensiones laborales y episodios irreligiosos.

El trasfondo socioeconómico de los incidentes anticlericales lo reconoce el párroco de Pinos Puente cuando señalaba que la hostilidad contra el clero era «más que contra la Iglesia contra los ricos". Según este sacerdote el incumplimiento de los propietarios, sobre todo durante el gobierno de Gil Robles, de las bases del trabajo tuvo como consecuencia que «esta

\footnotetext{
16 El Defensor de Granada, 7 abril 1934. Un año antes de que Gil Robles hablara de neutralidad, la derechista Carmen Barreda, en dos mítines celebrados en Motril, vituperó el anticlericalismo de los socialistas, enemigos de la cruz y destructores de cementerios, para acabar señalando la importancia de la educación de los hijos bajo los principios religiosos del catolicismo y de la moralidad. Lopez Martinez, M. y Gil. Bracero, R., Motril en guerra. De la República al franquismo (1931-1939). La utopía revolucionaria, Motril, Asukaria Mediterránea, 1997, p. 50.

17 Señala acertadamente Rodríguez Jiménez que "caracteriza a la derecha la instrumentalización de la religión como baluarte ante los cambios sociales y en tanto que cuerpo doctrinal para la defensa de los intereses de las clases propietarias». RODRiguez JiMÉnez, op. cit., p. 14.

18 Como iremos viendo a lo largo de este trabajo, y como ya estudié para el caso de la ciudad de Granada (BARrios RozúA, "Conflictividad social y destrucción de bienes religiosos en la ciudad de Granada durante la Segunda República", Revista del Centro de Estudios Históricos de Granada y su Reino, 9 (1995), pp. 185 a 211), buena parte de los sucesos anticlericales serán derivaciones violentas de huelgas, mitines obreros o movilizaciones antifascistas.
} 
antipatía de los obreros a los ricos" se hiciera extensiva "también contra la Iglesia, por creerla defensora de los ricos" ${ }^{19}$.

Ante la evidencia de que la Iglesia aparecía estrechamente vinculada a las derechas y a las clases acomodadas la jerarquía eclesiástica no hizo nada por romper esta imagen y acercarse a los problemas de los trabajadores. A ella más que a nadie correspondía dar un giro que habría desactivado en buena medida el anticlericalismo. Sin embargo, el miedo a distanciarse de sus "protectores" pudo más, y en ningủn momento planteó un cambio de política, aun consciente de que por ese camino la evangelización de las clases populares distanciadas del catolicismo no era posible. $\mathrm{Ni}$ siquiera la conciencia de que la propia religiosidad de las derechas era muchas veces superficial hizo replantearse a la Iglesia su actitud y, al igual que las derechas, culpó de todos los males a los sindicatos, partidos políticos y autoridades de izquierdas.

\section{El bloqueo de la legislación laica}

La legislación laica republicana ha sido objeto de atención preferente en numerosos trabajos. No voy por tanto a entretenerme en los acalorados debates parlamentarios a que dieron lugar y en repasar el contenido de cada uno de los decretos. Mi objetivo será incidir en aspectos como el clima de presión popular en el que se dictaron las medidas y la escasa efectividad que tuvieron debido a la resistencia de los católicos y las derechas.

Lo primero que hay que indicar es que el gobierno no disponía de un margen de maniobra demasiado amplio para decidir qué era más conveniente para la estabilidad de la República, si un pacto de no agresión con la Iglesia, o sea, el respeto de todos sus privilegios y conquistas logradas al amparo de la monarquía, o el modelo francés de Estado laico. La proclamación de la República había sido sorprendente por la tranquilidad con la que se desarrolló ${ }^{20}$, pero las grandes movilizaciones populares que la acompañaron mostraron la arrolladora entrada en escena de una izquierda apartada del poder durante casi seis décadas. Los gobernantes republicanos habrian de tener bien claro que era inviable gobernar de espaldas a unos sindicatos y partidos de izquierdas que vivian un espectacular crecimiento

19 Testimonio del sacerdote Toribio Molina, ADG, 190-F/116.

20 No obstante, hubo algunos incidentes en la provincia de Granada. En Motril los manifes. tantes penetraron en el Ayuntamiento y formaron una hoguera con retratos del rey y otros elementos de carácter monárquico. Lopez Martinez y GIL BRACERo, op. cit., p. 26. 
en su militancia. La extraordinaria politización de la sociedad y la importante conflictividad laboral revelan bien a las claras que ante las demandas populares sólo podía haber dos caminos, intentar satisfacerlas o recurrir a la represión como se venía haciendo desde hacía décadas, pero ahora con un mayor grado de violencia dada la envergadura de las protestas.

El intenso anticlericalismo de algunos sectores de la población, alentado por incidentes como los del cardenal Segura o el obispo Iruritia, se desveló con toda su crudeza en los disturbios que se iniciaron el 10 de mayo de 1931. A estos sucesos, bautizados como la "quema de conventos", suele achacarse el fin de toda posibilidad de entendimiento entre el Estado y la Iglesia en una interpretación cuanto menos aventurada. Habría que plantearse si realmente había alguna posibilidad de llegar a acuerdos que no pasaran por el inmovilismo o la regresión. Un clero menos integrista podría asumir que había llegado el momento de soltar lastre y mostrarse más dispuesto al diálogo y a la conciliación. Rechazar cualquier tipo de concesiones y apostar decididamente por la alianza con las derechas no era la actitud de una Iglesia dispuesta a acoger en su seno a toda la sociedad mediante la evangelización, sino aceptar que a una parte de los ciudadanos el catolicismo sólo se le podía imponer mediante la coerción.

El gobierno habría cometido una irresponsabilidad si no hubiera adoptado medidas laicizadoras de cierta contundencia después de los incidentes de mayo. No darse por aludido habría supuesto reconocer la incapacidad del marco legal para acoger reivindicaciones legitimas que si no encontraban su cauce bajo la República, ya sólo podrian materializarse por el camino de la insurrección revolucionaria. Recurrir a la represión era golpear las bases que con más o menos entusiasmo sostenían la República; y ello para intentar el vano ejercicio de atraer a quienes oscilaban entre un cínico accidentalismo y el deseo de reinstaurar una monarquía autoritaria ${ }^{21}$. Entre desatar la represión contra los anticlericales laminando el respaido popular, o intentar aplacar los ánimos con mano blanda, es lógico que muchas veces las autoridades prefirieran experimentar esta segunda vía, aunque con ello se facilitara un mayor número de asaltos a edificios religiosos.

24 El objetivo de la CEDA fue siempre el de acabar con el proyecto reformista republicano desde la propia República. Pero tras observar el ascenso del gobierno dictatorial de Dollfus en Austria (febrero de 1934) llegó a la conclusión de que éste era el camino para imponer su modelo de Estado cooperativo. El propio Gil Robles contactará con los militares durante el "bienio negro" para tantear la posibilidad de un golpe de Estado, aunque todavía no los encontró receptivos. Rodriguez Jimenez, op. cit., pp. 165 a 167. 
El mensaje que el gobierno captó tras la «quema de conventos» era que había que poner coto al clericalismo. Sólo desde posturas muy conservadoras o ciegas a la evidencia puede negarse la oportunidad de que las autoridades dieran pasos decididos en el camino de la laicización. ¿Qué otro camino podia emprenderse? ¿dejar que la antorcha popular hiciera lo que el gobierno no se decidía a afrontar? Incluso adoptando medidas represivas - la creación de la guardia de asalto data del 15 de mayo-, cualquier gobierno en su sano juicio habria impulsado algunas medias que demostraran que el poder no hacía oídos sordos al clamor de la calle.

Decidido a no perder la iniciativa, el gobierno provisional primero y el de Azaña después, desarrollarán una importante labor legislativa con el objetivo de construir un Estado laico: libertad religiosa, separación de la Iglesia y el Estado, extinción del presupuesto del clero en dos años, secularización de los cementerios, ley del divorcio, ley del matrimonio civil, eliminación de la instrucción religiosa obligatoria o expulsión de los jesuitas. La disolución de la Compañía de Jesús, una medida en la que siempre se ha querido ver un acto de torpeza política por su ineficacia - fue fácilmente burlada por los afectados ${ }^{22}$ - y gran resonancia, constituyó en realidad un acto de notable moderación. Con este gesto espectacular el gobierno pretendía contentar a quienes reivindicaban, empezando por los socialistas, la completa disolución de las órdenes religiosas ${ }^{23}$. Que los jesuitas hubieran sido expulsados en más de una ocasión desde tiempos de Carlos III demuestra que no era una medida disparatada. Un siglo antes se había ido mucho más lejos al cerrar todos los conventos masculinos y buena parte de los femeninos. También era más radical la legislación laica francesa dictada en 1905 y que inspiró en buena medida a los políticos españoles. Puede afirmarse por ello que las autoridades republicanas no se caracterizaron por su radicalismo, máxime si tenemos en cuenta las fuertes presiones que sufría en pro de la desaparición del clero regular. Todo parece indicar que la reacción del clero habría sido igualmente hostil si el gobierno se hubiera limitado sólo a adoptar medidas irrenunciables como la libertad religiosa y la separación de la Iglesia y el Estado ${ }^{24}$.

22 BRENAN, op. cit., p. 262 y JACKSON, op. cit., p. 61.

23 Raguer, «España ha dejado de ser católica», p. 150.

${ }^{24}$ Estas dos medidas levantaron airadas protestas de la jerarquía eclesiástica porque violaban el Concordato de 1851 (PAYNE, S., La primera democracia española. La Segunda República, 1931-1936, Barcelona, Paydós, 1995, p. 63). Recuérdese, además, la espectacular movilización que durante el Sexenio Revolucionario puso en marcha la Iglesia contra la libertad de cultos, BARRIOS RozÚA, Reforma urbana.t., p. 229 
Los partidos de derechas y el clero se movilizarán desde un primer momento para intentar bloquear la puesta en práctica de la legislación laica. Uno de los terrenos en los que más duro fue el enfrentamiento con los republicanos fue el de la enseñanza. Los colegios católicos habían mostrado en el pasado, pese a algunas obras de caridad, ser elitistas. Dado que la mitad de la población del país era analfabeta, la República consideró la enseñanza uno de los terrenos de acción decisivos, e impulsó la creación de una amplia red de colegios públicos. Paralelamente trató de imponer el laicismo en los centros ya existentes, fueran públicos o privados, en un esfuerzo por desarrollar un modelo de enseñanza igualitario.

Las restricciones impuestas por el gobierno a la enseñanza confesional encontraron una fuerte resistencia en los medios conservadores. El argumento central del clero y la derecha fue la «libertad de enseñanza», un principio al que se habian opuesto sistemáticamente durante la Restauración y la Dictadura, cuando incluso las universidades públicas llegaron a tener un fuerte control clerical ${ }^{25}$. Así pues, los católicos se movilizaron activamente para no perder un terreno tan estratégico y no sólo hubo duras campañas de prensa y manifestaciones, sino actos de violencia las más de las veces relacionados con la retirada de los crucifijos. Sirva de ejemplo el caso de Alhendín, donde en el transcurso de una procesión organizada por el párroco y el Centro Católico Agrario se interpretó la Marcha Real y se dieron gritos contra la República. Concluida la procesión los asistentes se dirigieron a la escuela, en la que irrumpieron tumultuosamente para entronizar el Crucifijo y romper el cuadro alegórico de la República. A continuación «los grupos asaltantes maltrataron al señor Matarán, arrojándole a empujones por la escalera". Los que intentaron defender al maestro también fueron agredidos. "Luego, los grupos derechistas la emprendieron a pedradas con el señor Matarán, obligándole a salir del pueblo y persiguiéndole hasta el río Dílar". La guardia civil se inhibió en este suceso y más tarde los jueces absolvieron a los responsables ${ }^{26}$.

También la Universidad de Granada será escenario de frecuentes roces entre la izquierdista Federación Universitaria Escolar (FUE) y la Federación Católica. Los enfrentamientos más graves del primer bienio ocurrieron

25 Hernández Armenteros, "La lucha por el control de la educación en la Segunda República. La presencia de la Iglesia en la enseñanza en la provincia de Jaén». Anuario de Historia Moderna y Contemporánea, 13 (1986), p. 295.

26 El Defensor, 8 mayo 1932 y 5 abril 1934. Otros muchos actos celebrados en defensa de la enseñanza confesional tuvieron un desarrollo pacífico. Es el caso de un acto llevado a cabo en Dúrcal en el que se pidió que el crucifijo volviera a presidir las escuelas. El Defensor, 20 febrero 1932. 
el 17 de noviembre a raíz de una huelga convocada por estos últimos en protesta por las jubilaciones de unos jueces y magistrados conservadores. Los alumnos que decidieron no secundar la protesta en la Facultad de Derecho fueron blanco de tomates arrojados por los católicos. Esto indignó a los estudiantes izquierdistas, que se dirigieron en manifestación a la plaza de las Pasiegas y apedrearon la Casa del Estudiante (residencia social de los estudiantes católicos) y luego intentaron asaltar el diario ldeal, que no perdía ocasión de atacar a la FUE. Días después los miembros de la Federación Católica abuchearon al nuevo rector de la Universidad, el catedrático socialista Alejandro Otero ${ }^{27}$.

No menos violencia alcanzó a veces la resistencia contra la libertad de cultos. Los pocos protestantes que había en la provincia de Granada fueron los que más la padecieron. En Alomartes un mitin de pastores evangélicos fue interrumpido por una persona que dio vivas a la religión católica y efectuó un disparó al aire; para colmo la guardia civil quiso disolver este acto aprovechando el incidente, a lo que se opuso el alcalde ${ }^{28}$. En íllora un pastor evangélico aseguraba que él y sus feligreses, todos de condición humilde, eran perseguidos por las fuerzas católicas y los propietarios de esa localidad ${ }^{29}$. Ante la proliferación de episodios como estos no es de extrañar que los miembros de las Juventudes Evangélicas de España, cansados de verse "perseguidos y maltratados por la intransigencia del clericalismo", se mostraran partidarios "de un régimen de libertad de conciencia y justicia social» como la República y respaldaran a las formaciones de izquierdas ${ }^{30}$.

Será en el "bienio negro» cuando la resistencia a la legislación laicizadora alcance su apogeo. El nuevo gobierno conservador convertirá en letra muerta la legislación laica de la anterior etapa, aunque en teoría siga vigente, a la par que aumentará las partidas presupuestarias para el clero. Desactivada toda política laica dirigida desde el gobierno central, tocaba la más difícil tarea de acabar con la que pudieran desarrollar los ayuntamientos y las clases populares. Contra ellos se desencadenaron durísimas oleadas represivas que tuvieron como justificaciones la insurrección anarquista de diciembre de 1933, la huelga campesina del verano de 1934 y la revolución de Asturias. Los ayuntamientos socialistas fueron destituidos por el gobernador civil y sustituidos por juntas gestoras de derechas. Paralelamente numerosos líderes izquierdistas eran encarcelados y buena

\footnotetext{
El Defensor, 18 y 22 noviembre 1932.

El Defensor, 13 y 15 noviembre 1931.

El Defensor, 1 diciembre 1935.

El Defensor, 29 enero 1936.
} 
parte de las sedes obreras clausuradas. Este último hecho tiene un especial significado: la casa del pueblo era el local en el que, además de celebrarse reuniones, también se realizaban numerosos actos sociales; era el "templo" de las gentes de izquierdas ${ }^{31}$. Su cierre por la guardia civil o grupos derechistas, muchas veces violento y destructivo, despertará deseos de venganza entre los afectados, que cuando tengan la posibilidad, y ésta se presentará tras el triunfo del Frente Popular, se tomarán la revancha asaltando los "templos de las derechas", las iglesias.

Durante este periodo se multiplican los juicios contra los «petardistas" y las personas que participaron en los asaltos a edificios religiosos durante el anterior periodo republicano. Habrá sentencias absolutorias por falta de pruebas en alguna ocasión, lo que despertará las iras del Ideal, convencido siempre de la culpabilidad de los encausados, pero la tónica general será la de elevadas condenas de prisión ${ }^{32}$. En este clima no puede sorprender que el anarquista granadino José Alcántara García, lider de una escisión moderada de la CNT y fundador del Partido Sindicalista, fuera condenado a un día de arresto y quinientas pesetas de multa por publicar un libelo contra la religión católica ${ }^{33}$.

A la vez que se neutraliza al movimiento obrero mediante la represión, la Iglesia y las formaciones conservadoras desarrollarán todo un programa de recristianización que, si bien fracasa en su intento de implantar el catolicismo en las masas trabajadoras que le son hostiles o indiferentes, sí conseguirá movilizar y aglutinar en posiciones cada vez más derechistas a buena parte de aquellos que hacen de la religión católica una de sus principales señas de identidad. En este proceso fue de inestimable ayuda el sentimiento de naufragio moral en que se vieron sumidos los creyentes al presenciar los numerosos sucesos irreverentes e iconoclastas protagonizados grupos de anticlericales.

La ofensiva recristianizadora se llevará a la práctica en varios frentes: el intento de resucitar los mermados sindicatos confesionales, una reactivación de las procesiones y romerías de la que el diario ldeal se hace eco con entusiasmo ${ }^{34}$ y las primeras tentativas de reconstruir los templos y

\footnotetext{
3. Véase el reciente trabajo de Luis Martin, F. y ARIAs González, L., Las casas del pueblo socialistas en España (1900-1936), Barcelona, Ariel, 1997.

32 El 5 de noviembre se celebró uno de los más significativos juicios contra "petardistas". El 24 de abril de 1935 se publican noticias sobre el juicio a siete presuntos autores de los asaltos a conventos de los dias 12 y 13 de mayo de 1931. Veanse Ideal y El Defensor.

33 Ideal, 21 octubre 1934.

34 En Granada, por ejemplo, se celebra con esplendor, después de tres años sin salir, la procesión de la Virgen de las Angustias. El Defensor, 19 septiembre 1934.
} 
cruces destruidos durante el anterior periodo ${ }^{35}$. En este clima no puede sorprender que el /deal encabece un amplio artículo con el siguiente titular: «En el arte, el año 1934 inicia la vuelta a lo religioso». El diario confesional, en plena época de la vanguardias, habla de un "renacimiento artístico" que consiste en exposiciones juveniles sobre temas religiosos, obras artísticas de estilo neobarroco, etc ${ }^{36}$.

Pero la recristianización y el "orden social» impuestos a base de estados de emergencia, encarcelamiento de líderes obreros y suspensión de ayuntamientos de izquierdas será un fracaso ${ }^{37}$. Sólo las víctimas mortales y los incidentes anticlericales de los sucesos de octubre de 1934 superarán con creces a todos los hechos de análoga naturaleza ocurridos a lo largo de la primera etapa de la República. La Iglesia, lejos de apostar ahora por la concilización, promoverá la celebración de funerales por las víctimas de los revolucionarios y no tendrá palabras de consuelo para las víctimas aún más numerosas de la izquierda. Es más, el diario católico ldeal abrirá en Granada una suscripción popular en favor de la guardia civil y los militares, en agradecimiento a la labor represiva desarrollada durante el levantamiento ${ }^{38}$.

La evocación del martirologio y la persecución, temas recurrentes de la Iglesia por aquellos días, no sólo se apoyará en los acontecimientos de Asturias, sino que retomará temas históricos haciendo una peculiar lectura de ellos. En Granada y Almería despertará especial interés entre los ambientes católicos el recuerdo de la Guerra de las Alpujarras (1568-1570), en las que perecieron numerosos sacerdotes y cristianos. Es evidente el paralelismo que se trata de establecer entre la insurrección de las Alpujarras y la de octubre de 1934, entre los infieles moriscos y los revolucionarios izquierdistas. Ideal publicará algunos artículos referentes al tema, y a principios de 1935 aparecerá el libro Mártires de la Alpujarra en la rebelión de los moriscos, del padre Francisco A. Hitos. Por las mismas fechas se constituirá un Comité Pro Mártires de la Alpujarra para trabajar por su canonización ${ }^{39}$.

35 Nada más significativo que la erección de cruces, de io que tenemos algunos ejemplos en Granada, Loja y otras localidades (Ideal, 3 noviembre 1934) o el primer proyecto para reconstruir la iglesia de San Nicolás que encabezan aquellos que tras el golpe de Estado serán las personas más significadas del mundo de la cultura: Antonio Gallego Burin. Prieto Moreno, Emilio Orozco Diaz, Jesús Bermúdez Pareja, Marino Antequera, etc. (Ideal, 8 mayo 1935, 4 y 6 junio 1935).

36 Ideal, 1 enero 1935.

37 JACKSON, op. cit., p. 151.

38 Hay noticias en prácticamente todos los números de ldeal de noviembre de 1934

39 Véase el ensayo introductorio de Barrios AGULLRA (en especial pp. XXVI a XXVIII) a la edición facsímil de Hitos, F., Mártires de la Alpujarra en la rebelión de los moriscos (1568), Universidad de Granada, 1993 (primera edición en Madrid, Apostolado de la Prensa, 1935). 
La actitud martirial que empieza a observarse en la Iglesia coincide en el tiempo con la fascistización de la CEDA y sus juventudes, y al reforzamiento de las organizaciones de extrema derecha: monárquicos de Renovación española, falangistas y carlistas. La tentación del golpe de Estado se asienta cada vez más en la derecha, mientras que los medios de comunicación de la Iglesia no le hacen ascos a la idea y ven con creciente admiración la Italia de Musolini y la Alemania de Hitler. Cuando la izquierda gane las elecciones de febrero de 1936, la derecha mirará a los militares como los salvadores de la patria. Fracasado el camino del accidentalismo ante la República y cerradas las puertas a cualquier tipo de concesiones al laicismo, es evidente que la gran mayoría de la Iglesia española ve con buenos ojos una involución autoritaria. Aunque no participará en la gestación del golpe de Estado, sí que lo alentará desde su prensa, como puede comprobarse, por ejemplo, en el diario granadino Ideal.

\section{EL DESBORDAMIENTO DE LA REPÚBLICA: "LAICIZACIÓN POPULAR"}

\section{El anticlericalismo en el movimiento obrero de la provincia de Granada}

Vista la resistencia clerical que encontró la legislación republicana, llega el turno de estudiar la presión ejercida desde las organizaciones populares, una presión que desbordó por la izquierda las medidas legislativas y promovió la laicización por la vía de los hechos.

Con la proclamación de la Segunda República serán los anarcosindicalistas, organizados en la Federación Local de Sindicatos Únicos (FLSU), los que destaquen como principal fuerza sindical en la capital granadina ${ }^{40}$. En la provincia, sin embargo, su implantación no pasará de tener un carácter secundario frente a la Unión General de los Trabajadores. La investigación llevada a cabo por Alarcón Caballero indica que el sindicato anarquista sólo existía en una treintena de las doscientas localidades de la

40 Su número de afiliados, concentrados en la capital, fue de unos 8.000 trabajadores en 1931, para alcanzar entre 15.000 y 25.000 a finales de 1932 y retornar en 1936 a las cifras iniciales, tanto por haber sido víctimas prioritarias de la represión, como por sus propias disensiones internas y errores tácticos. Sobre la historia e implantación del anarcosindicalismo en Granada y su provincia véase CALERO AMOR, A. M., Historia del movimiento obrero en Granada (1909-1923), Madrid, Tecnos, 1973, pp. 128 a 162, MauriCE, J., El anarquismo andaluz. Campesinos y sindicalistas (1868-1936), Barcelona, Crítica, 1990, p. 30; Alarcón Caballero, J. A., El Movimiento Obrero en Granada en la Segunda República (1931-1936), Granada, Diputación Provincial, 1990., p. 262 a 276, y LÓPEz MARTínez, op. cit., p. 203. 
provincia, la mayoria de ellas de la Vega y la costa. En los pocos pueblos en los que tenía presencia estaba en franca minoría. En realidad, sus bases sólo eran destacadas en Motril, Pinos Puente y Maracena.

En los dos primeros años de la República la dirección granadina estuvo controlada por la rama más moderada del anarquismo, los llamados "treintistas", corriente partidaria de una labor sindical desvinculada en lo posible de las acciones violentas y poco amiga de un choque frontal con la República. Sin embargo, el sector más radical, impulsado por la Federación Anarquista Ibérica (FAl), se irá fortaleciendo hasta hacerse con la dirección. Se producirá entonces una escisión y los "treintistas» formarán en 1933 la Federación Sindicalista Libertaria (FSL) y más tarde el Partido Sindicalista, organizaciones que tendrán una reducida implantación.

A la FAl hay que atribuir la iniciativa de tres insurrecciones fallidas, de una larga lista de acciones violentas, que en muchos casos tuvieron como objetivo los bienes religiosos, y de una agotadora sucesión de huelgas generales. La estrategia faísta, destinada a minar la República y allanar el camino a la revolución social, fue determinante para la consolidación de la CNT como principal fuerza sindical en la ciudad de Granada y forzó gradualmente a la UGT a llevar una política más combativa, dado que corría el riesgo de perder sus bases. Sin embargo, la estrategia faísta acabó por producir un fuerte desgaste en la militancia de la CNT y atrajo sobre este sindicato una dura e indiscriminada represión ya durante el gobierno de izquierdas, y aún más durante el "bienio negro", en el cual el sindicato quedó desmantelado en buena parte.

Las Juventudes Libertarias estuvieron especialmente influidas por la FAl, y de hecho jugaron un papel muy activo en los disturbios que vivió la ciudad. La prensa, sobre todo el diario católico ldeal, relacionará en varias ocasiones a militantes de esta organización con los atentados contra bienes religiosos. De hecho, las edades de la mayoria de los detenidos por estos incidentes suele oscilar entre los quince y los veinticinco años.

Que los anarquistas fueran los principales responsables de los atentados contra bienes religiosos en la ciudad de Granada es algo que ya he demostrado en otro trabajo ${ }^{41}$; pero tal consideración no puede hacerse extensiva a la provincia, donde su implantación era tan débil que difícilmente podían tomar iniciativas e iban a remolque de los socialistas. Sirva

41 BąrRios Rozúa, op. cit., pp. 185 a 211. En este artículo realizo un detallado relato de los incidentes anticlericales acaecidos en la ciudad de Granada durante la República; de él extraigo las breves notas que dedico a estos sucesos en las próximas páginas. 
como ejemplo la escasa repercusión más allá de la ciudad de las dos insurrecciones promovidas por la FAI en 1933.

Si bien el anticlericalismo era patrimonio de toda la izquierda, y los socialistas y comunistas estuvieron implicados en infinidad de enfrentamientos de ésta índole, en ningún colectivo alcanzó tal relevancia esta problemática como en el anarcosindicalismo. No en vano el anticlericalismo se convierte muchas veces en una de las principales señas de identidad ácratas. Esta animadversión hacia el catolicismo era en buena medida heredera de la larga tradición anticlerical del liberalismo español. Los anarquistas denunciaban de la Iglesia su apoyo al poder establecido, su oscurantismo y resistencia ante los progresos de la ciencia, y su corrupción y privilegios, los cuales contrastaban con el empeño del clero en inculcar en las clases oprimidas el desprecio hacia los bienes materiales y el conformismo ante su situación social ${ }^{42}$.

Los socialistas aglutinaban a la mayoria del movimiento obrero y del republicanismo en la provincia de Granada, donde la principal organización sindical era la UGT y el PSOE constituía el partido de izquierdas más votado ${ }^{43}$. La estrategia inicial del PSOE y la UGT estuvo condicionada por la participación en el gobierno de Azaña, lo que les llevó a intentar contener los procesos huelguísticos e imposibilitó toda unidad de acción con la CNT. Los socialistas no dudaron en condenar, unas veces

42 De hecho en el pensamiento ácrata no existe sólo un rechazo a lo clerical, sino a todo lo que se refiera a religión. Para ellos Dios es una invención de los hombres del pasado para explicar los fenómenos naturales que escapaban a su comprensión, invento utilizado después por una casta sacerdotal para someter al pueblo. Para acabar con la alienación de la libertad humana, máximo valor para los anarquistas, no sólo es preciso destruir el Estado y la jerarquía eclesiástica, sino también la autoridad divina, que desplaza al hombre de su lugar central en el Universo y se apropia de sus atributos esenciales: la razón, el sentimiento y la voluntad. Véase Áv VAREZ JUNCO, La ideologia política del anarquismo español (1868-1910), Madrid, Siglo XXI, 1991, pp. 29 a 36, 77 a 85 y 204 a 214.

43 A mediados de 1931 la UGT tendría unos 15.000 afiliados, cifra que crecería hasta unos 50.000 en el momento de mayor apogeo, para decaer durante el "bienio negro" y recuperarse después de las elecciones de febrero de 1936. El espectacular desarrollo de la UGT estuvo favorecido especialmente por la legislación laboral puesta en marcha por el ministro Largo Caballero durante la primera etapa de la República. El número de militantes y de agrupaciones del PSOE queda muy por debajo, pero esto es bastante relativo, porque en aquellas localidades donde no existía el partido como tal, el sindicato impulsaba sus candidaturas electorales. Alarcón Caballero estima que en 1932 podria encuadrar en torno a 4.000 o 5.000 personas; además, detentaba un importante número de alcaldias y la Diputación Provincial, aunque nunca hubo ningún gobernador civil de esta formación. La implantación socialista era desigual: muy notable en las zonas de Iznalloz, Montefrio, Santa Fe, Alhama y Motril, pero reducida en la Alpujarra y muy por debajo de los anarcosindicalistas en la capital. Sobre la historia e implantación del socialismo en la provincia de Granada véase Calero Amor, op. cit., pp. 141, 151 y 160 a 162, Alarcon Caballero, op. cit., pp. 175 a 184 y LÓPEz MARTINEZ, op. cit., pp. 197 a 199. 
con más matizaciones que otras, los incidentes violentos que se vivieron en la ciudad. No pudieron evitar, sin embargo, que sus bases y los alcaldes de algunos de sus ayuntamientos se vieran implicados en incidentes anticlericales.

La postura reformista del PSOE, impulsada por unos dirigentes procedentes mayoritariamente de profesiones liberales, encontrará crecientes dificultades por el boicoteo de la patronal a la legislación laboral y social republicana, lo que frustrará las expectativas de las bases socialistas y les hará ver con crecientes simpatías la dinámica combativa de la CNT. En ello colaboró el fuerte crecimiento del PSOE y la UGT, con el inevitable ascenso de nuevos líderes obreros y campesinos más radicales. En estas condiciones el socialismo irá virando progresivamente hacia las posturas izquierdistas propugnadas por Largo Caballero, una dinámica que se verá favorecida por las duras lecciones que por esas fechas ofrezcan los socialdemócratas de Alemania y Austria. Los socialistas llegarán a la conclusión de que la debilidad mostrada por sus compañeros germanos propició la derrota y que la única forma de evitar el ascenso del fascismo es combatirlo con energía. La reorganización de las derechas acentuará sus temores, y aún más la victoria electoral de éstas, con el subsiguiente retroceso que experimenten las conquistas del anterior periodo. Las tesis de la izquierda socialista se imponen finalmente y el PSOE promueve la huelga revolucionaria de 1934. La torpeza organizativa del PSOE, que ni siquiera logra el respaldo de la CNT, y la represión preventiva desatada por el Gobierno Civil la hacen fracasar por completo en Granada. Las autoridades derechistas aprovecharán la situación para destituir a los alcaldes socialistas que quedaban, cerrar las sedes obreras y encarcelar a la mayoria de los dirigentes izquierdistas.

EI PSOE y la UGT quedarán aletargados hasta las elecciones de febrero de 1936. El triunfo del Frente Popular propiciará la amnistía para los presos políticos, la reapertura de las casas del pueblo y la restitución a los socialistas de'los ayuntamientos que habían perdido. EI PSOE está ahora mucho más radicalizado - lo demuestra la unificación de sus juventudes con las de los comunistas- y no puede evitar que el espíritu revanchista alcance a sus militantes después de las vejaciones sufridas durante el "bienio negro". No es de extrañar, pues, que los socialistas estén implicados en muchos de los incidentes anticlericales que jalonan los últimos meses de la República.

El anticlericalismo de los dirigentes socialistas no era nada proclive a justificar los asaltos a centros católicos y se mostraba respetuoso con las creencias religiosas de los individuos. EI PSOE no aspiraba ni mucho 
menos a barrer a la Iglesia católica del suelo ibérico, como pretendian los anarquistas, sino que se conformaba con lograr una efectiva laicización y terminar con las intromisiones del clero en la vida política y la enseñanza. En esta línea iban las reflexiones de Fernando de los Ríos cuando afirmaba que

"por respeto a la Iglesia y al Estado, no pueden confundirse las dos instituciones. Al Estado no se le puede exigir que tenga ni pague una religión, $\mathrm{ni}$ a la Iglesia le conviene garantizar su vida con otra cosa que no sea el fervor y la ayuda económica de quienes sienten aquel ideal religioso" ${ }^{44}$.

O cuando más tarde el ministro granadino aseguraba que la reforma emprendida por el Gobierno era «de tipo clerical, no religioso", porque "no es el problema religioso el que se tocó cuando fue separada la Iglesia del Estado", ya que el "problema religioso vive en la intimidad de las conciencias y de los templos y nosotros lo respetamos" ${ }^{45}$. De hecho, una rígida interpretación de la doctrina marxista lleva a los socialistas a asegurar que el problema de la religión es completamente secundario frente al de la emancipación económica y que una vez lograda ésta las nuevas condiciones sociales favorecerán la desaparición de aquella ${ }^{46}$.

La cúpula del PSOE confiará en la labor reformista del Gobierno respecto al problema del clero, al igual que lo hace en materia laboral, pese a que la legislación queda por debajo de sus aspiraciones, sobre todo por no suprimir las órdenes religiosas ${ }^{47}$. No siempre ocurrirá lo mismo con los dirigentes locales y, sobre todo, con las cada vez más radicalizadas bases, que han sufrido durante décadas el clericalismo y ahora ven como la legislación laicizadora se aplica con lentitud, mientras que la lglesia reacciona con energia y contraataca respaldada por las derechas. Es por ello fácilmente comprensible la participación de las bases socialistas

\footnotetext{
44 El Defensor, 25 junio 1931

45 El Defensor, 3 mayo 1932.
}

46 Este tipo de plantamientos aparecen con toda claridad en Pablo Iglesias, quien aseguraba que "para un verdadero socialista el enemigo principal no es el clericalismo, sino el capitalismo". Lo que según él "no obsta para que los socialistas hagan todo lo que puedan contra la preponderancia del clericalismo, que ha venido a ser, más o menos voluntariamente, según los países, un poderoso auxiliar de las clases explotadoras". Pero insiste en que "excitar al proletariado a que dirija su actividad y su energía contra los clericales antes que contra los patronos, es el error más grave de que pueden ser víctimas los que aspiran a terminar con la explotación humana". ARBELOA y Muru, V. M., Socialismo y anticlericalismo, Madrid, Taurus, 1973, pp. 158-159.

${ }_{47}$ La corporación municipal de Montefrío, socialista, solicitará a principios de la república la disolución de las órdenes religiosas e incautación de sus bienes (El Defensor, 18 julio 1931). La misma petición harán cinco años después las Juventudes Socialistas en un mitin celebrado en Granada (El Defensor, 12 abrił 1936). 
en muchos de los episodios anticlericales que se vivirán en la provincia de Granada.

Los comunistas, cuyo partido fue legalizado en Granada el 19 de junio de 1931, sólo tenían presencia en aquellos momentos en la capital y en Maracena ${ }^{48}$. En un mitin de controversia entre el PCE y la CNT celebrado en diciembre de 1931 los comunistas tuvieron que recurrir a traer sus simpatizantes de varias localidades andaluzas. Durante este acto el orador José Bullejos afirmó que la oposición comunista a la Iglesia era sólo un elemento más de su confrontación con las clases privilegiadas, y no un problema religioso ${ }^{49}$.

El despegue del PCE en la provincia de Granada no llegará hasta 1936 cuando la radicalización del PSOE y la UGT lleve a algunos de sus militantes a pasarse a los comunistas. Además, la activa participación de los comunistas en favor del Frente Popular durante las elecciones de febrero de 1936, a pesar de no llevar candidatos en las listas, les permitió extenderse por la provincia. Durante las elecciones los oradores comunistas aludieron ocasionalmente y de forma secundaria al problema religioso. En un mítin en Iznalloz, por ejemplo, José Pérez alertó a los campesinos de lo que suponia "el catolicismo y el fanatismo religioso" 50 .

El partido alcanzará pronto los 1.600 militantes y conseguirá concejales en diversas localidades cuando sean nombradas las nuevas comisiones gestoras. El creciente vigor del PCE quedó de manifiesto en un mitin ante tres mil personas celebrado en el Teatro Cervantes, durante el cual un miembro del Comité Central hizo "constar que el Partido Comunista no va contra la Religión sino contra el clericalismo".

La participación del PCE en acontecimientos anticlericales antes de 1936 es más que improbable debido a su escasísima implantación. Tras la

48 EI PCE no superará el centenar de militantes en el primer bienio republicano, a pesar de la constitución de las juventudes, y su extensión a otras localidades granadinas: Íllora, Rubite, Salar... La debilidad del partido queda de manifiesto en que esta es la única provincia de Andalucía en la que es incapaz de construir su sindicato afin, la CGTU, y se ve obligado a trabajar en la UGT y la CNT. Hubo una pequeña aportación de militantes en febrero de 1933, cuando la mayoría de los dos centenares de miembros del Partido Social Revolucionario (PSR) decidieron ingresar en el PCE. Este aporte militante no bastó para sacar a los comunistas de su marginalidad. ALARCÓN CABALLERO, op. cit, pp. 304 a 328.

49 «La revolución tiene que hacerse para que la tierra, propiedad de los grandes terratenientes, sea expropiada y entregada, sin indemnización alguna a los campesinos pobres, a los obreros agricolas, porque la revolución tiene que destruir todo el Poder, todo el privilegio del alto clero, de los grandes dignatarios de la Iglesia, porque la revolución tiene en fin que dirigirse contra grandes banqueros como Urquijo, contra toda la burguesía social y financiera de España". El Defensor, 28 diciembre 1931.

50 El Defensor, 4 febrero 1936. 
victoria del Frente Popular su número de militantes ya sí lo convierten en un colectivo a tener en cuenta. Por las mismas razones que el PSOE y la UGT, los dirigentes comunistas, aunque eran abiertamente anticlericales, se mostraban menos preocupados por la cuestión que los anarquistas. El PCE siempre distinguió, al menos formalmente, entre un clero objeto de sus críticas, y unas creencias religiosas que respetaba. De todas formas, la actitud de las bases comunistas, al igual que las de los socialistas, era con toda seguridad más espontánea y radical que la de sus dirigentes.

La recepción popular de la legislación republicana y la subversión de las prácticas tradicionales

Las medidas laicizadoras adoptadas desde el gobierno no desactivaron el anticlericalismo que latía en la calle, aunque seguramente contribuyeron a evitar incidentes aún más graves. Dependiendo de la adscripción ideológica de las autoridades municipales la legislación fue aplicada con rigor o, por el contrario, ignorada. Los propios simpatizantes o militantes de la izquierda trataron en ocasiones de hacer cumplir estos decretos a su manera; otras veces iban más lejos en sus deseos laicizadores y desbordaban claramente la legalidad. La población distanciada de la Iglesia, por su parte, iba desterrando de su vida incluso los ritos más asentados de la tradición católica.

Los entierros laicos, los matrimonios civiles y la ausencia de bautismos son algunos de los hechos que los párrocos citan como prueba del clima de desprecio hacia la religión al que se tenían que enfrentar cotidianamente. EI párroco de Escúzar, por ejemplo, declara que tuvo "muchos disgustos en los bautismos" y que hubo varios entierros civiles o con la presencia de la bandera roja. Algunos sacerdotes se negaban a bautizar a niños porque sus padres eran conocidos izquierdistas. Otras veces eran los católicos de condición humilde los que rechazaban los usuales ritos religiosos por el manifiesto derechismo del párroco. Es el caso de Pórtugos, donde eran muchas las familias católicas que enterraban a sus pariertes de forma civil porque estaban molestas con la visible ideología reaccionaria del párroco. La situación llegó a tal extremo que el cura hubo de escribir una carta al Ideal asegurando a sus feligreses que él votaba en blanco en las elecciones ${ }^{51}$.

Las procesiones fueron un constante motivo de polémica durante el quinquenio republicano. Para la izquierda las procesiones eran actos políticos de

51 Ideal, 27 julio 1932. 
los enemigos de la República, pues las solian encabezar los elementos más conservadores de cada localidad: propietarios, guardia civil y sacerdotes. A veces era denegado el permiso de manifestación a las organizaciones obreras por coincidir la hora con algún desfile religioso, lo cual ocasionaba protestas e incidentes ${ }^{52}$. En otras ocasiones era una procesión la que veía prohibida su salida por orden de las autoridades. Pero no siempre eran respetadas estas decisiones políticas, como ocurrió en la localidad almeriense de Ohanes, donde uen una ocasión los jóvenes de derechas sacaron una procesión contra la prohibición del Alcalde» ${ }^{53}$. En estos casos de desobediencia a la autoridad era frecuente que el Gobierno Civil adoptara medidas sancionadoras, tales como la clausura del local de la asociación promotora del acto, caso de la Juventud Católica de Dúrcal, o multas y amonestaciones al párroco ${ }^{54}$. También podian ser sancionados los vecinos que habian protagonizado el acto aduciendo la "ostentación de insignias, pretexto las más de las veces para significarse en contra del régimen republicano" ${ }^{55}$. Y es que la exhibición de simbología monárquica era causa segura de conflicto. La festividad del Corpus de 1931 revistió especial conflictividad en Jayena porque el párroco y el secretario del Ayuntamiento colgaron en sus ventanas banderas monárquicas. Un indignado grupo de afiliados del Centro Obrero Socialista las retiraron y quemaron en la vía pública armando tal revuelo que fue preciso suspender la procesión programada ${ }^{56}$.

Las procesiones autorizadas podían enfrentarse a la hostilidad de izquierdistas que proferían gritos anticlericales al paso de las imágenes ${ }^{57}$. Lo malo es que estas situaciones no siempre se quedaban en enfrentamientos verbales. En Huéscar, por ejemplo, era costrumbre que al concluir la procesión de los patronos de la localidad, San Nunilón y Santa Alodia, los fieles se disputaran las imágenes. Esta circunstancia fue aprovechada por un grupo de izquierdistas para apoderarse de las esculturas y llevarlas en procesión bufa al Centro Agrario. Alli se produjo un enfrentamiento entre anticlericales y católicos, con algún disparo incluido. El alcalde logró calmar los ánimos y el incidente no llegó a mayores, aunque dejó de manifiesto que ni los patronos de las localidades eran respetados ${ }^{58}$.

loeal, 18 junio 1932.

Testimonio del sacerdote Alberto Gómez. ADG, 190-F/108

Amonestaciones a párrocos hubo por ejemplo en Loja, Motril, Pinos Puente o Salobreña (ADG, 190-F/87, 100, 116 y 126) y multas en Alfacar y Pórtugos (ADG, 190-F/7 y 120, e /deal, 13 junio 1936).

55 Ideal, 28 septiembre 1932, 8 febrero 1933,6 y 7 abril 1933

56 El Defensor, 6 junio 1931

57 Es, por ejemplo, el caso de Murtas. ADG, 190-F/101.

58 El Defensor, 30 marzo y 5 abril 1932. 
No menos incidentada fue una procesión del Sagrado Corazón de Jesús celebrada en Marchal el 13 de junio. Según el párroco, cuando la procesión regresaba a la iglesia un grupo de personas vinculadas a la casa del pueblo se situaron frente a ella y efectuaron al menos quince disparos, sin que hubiera heridos. Al parecer los izquierdistas estaban molestos porque el alcalde les denegó el permiso para celebrar una manifestación a la misma hora. La guardia civil detuvo a diez personas, entre ellas dos mujeres ${ }^{59}$.

Pero el incidente más grave se produjo en Cogollos Vega el 13 de octubre de 1932. La tradicional procesión del Santisimo Sacramento venía aquel año precedida de una fuerte polémica, hasta el punto de que el párroco se planteó la posibilidad de suspenderla. Sin embargo, algunas personas le hicieron desistir de semejante idea y la procesión partió de la iglesia como otros años. Grupos de anticlericales, algunos de ellos llegados de otras localidades, dieron gritos contra el clero y a favor de la República, lo que fue contestado con vivas a Cristo Rey. Los ánimos se exaltaron aún más al pasar por la taberna del izquierdista Francisco López. Poco después, en medio de consignas a favor y en contra del clero, se inició un tiroteo sobre el que existen diferentes versiones. El párroco y el alcalde derechista aseguran que fueron unos comunistas los únicos que dispararon. Según los socialistas, primero dispararon los elementos del Centro Agrario y otras personas que participaban en la procesión, y añaden que en la localidad nunca hubo comunistas. Como consecuencia del tiroteo resultó muerta María López Chacona y quedaron heridos los párrocos de Cogollos Vega y de Maracena, además de otras cuatro personas. Tras el trágico incidente los reporteros de El Defensor pudieron comprobar que a las afueras del pueblo se habian apostado piquetes para controlar los accesos e impedir la salida de los curas, los cuales se refugiaron en una casa de la localidad. La guardia civil detendrá, parece ser que arbitrariamente, a dos obreros a los que posteriormente tendrá que poner en libertad ${ }^{60}$.

En Granada una iniciativa municipal aprobada por la mayoría de los concejales e inspirada en las normas dictadas por el gobierno de la República acordó que los cargos electos municipales no acudieran a actos religiosos ${ }^{61}$. Ello llevó a suspender durante tres años la procesión de las Angustias, pues los mayordomos de la hermandad preferían no salir ante

59 Ideal, 14 junio 1932

60 Ideal y El Defensor, 14 y 15 octubre 1932; ADG, 190-F/42.

61 El Defensor, 7 junio 1931. 
la ausencia de autoridades políticas y militares, dado que esto deslucia el acto ${ }^{62}$. Otras procesiones tradicionales, como la del Viernes Santo o la del Corpus se celebrarían dentro de la Catedral para evitar incidentes. Los tronos recorrían las naves con el público distribuido a los lados ${ }^{63}$. También la fiesta del 2 de enero, día de la Toma de Granada por las tropas de los Reyes Católicos, tendría durante la República un estricto carácter laico, lo que obligó a la Iglesia a celebrarlo por su cuenta en la Capilla Real ${ }^{64}$.

No fueron las procesiones las únicas manifestaciones de culto externo que tuvieron ocasionales problemas. Algunos ayuntamientos socialistas prohibieron también las misas al aire libre e incluso los viáticos y entierros según el rito católico, aunque esto ocurrió rara vez. Además, estos actos religiosos estaban expuestos a que grupos de personas, sobre todo niños y jóvenes, las hostigaran con blasfemias.

En las fiestas y ferias de los pueblos tampoco faltaron los problemas. En Moclín las fiestas fueron polémicas porque las izquierdas se sintieron molestas por la celebración de actos religiosos en lo que consideraban era una festividad laica ${ }^{65}$. En Láchar ocurrió lo contrario tal y como nos cuenta El Defensor.

"Con extraordinaria animación se vienen celebrando la fiesta y festejos de esta localidad, no muy del agrado de estos caciques, dado el carácter laico que se les ha dado a las mismas, ya que la sociedad obrera ha sido la encargada de su organización» ${ }^{66}$.

De la misma manera que los izquierdistas corearon en alguna ocasión frases provocadoras contra celebraciones religiosas, también hubo derechistas que hicieron lo propio frente a las organizaciones obreras, como los gritos que un grupo de personas dio a favor de Cristo Rey en la localidad de Ohanes ${ }^{67}$. No obstante, los principales escollos para el libre desenvolvimiento de los actos del movimiento obrero fueron la guardia civil y la guardia de asalto.

Las mofas contra las prácticas católicas eran frecuentes y no se limitaban a escenarios como las celebraciones rituales. En Granada, por ejemplo, la

\footnotetext{
El Defensor. 5 septiembre 1931.

El Defensor, 2 abril 1934 y El Noticiero Granadino, 3 abril 1934.

El Defensor, 3 enero 1932 y la misma fecha de los años siguientes.

El Defensor, 11 octubre 1931.

El Defensor, 8 octubre 1931.

67 Los derechistas, tres hombres y dos mujeres, fueron momentáneamente detenidos. ADG,
} $190-\mathrm{F} / 108$. 
conservadora Asociación Femenina de Educación Ciudadana presentó una denuncia al gobernador civil porque hay "grupos que van por las calles burlándose de los emblemas de la religión católica", y citó el ejemplo de una joven a la que habian colgado en la espalda un crucifijo recortado en papel con un dibujo obsceno ${ }^{68}$.

Los intentos de limitar el toque de campanas a determinadas horas del dia también fueron problemáticos y en algunas ocasiones acabaron con multas por la desobediencia de los párrocos ${ }^{69}$. La aplicación de esta medida dependía, como casi siempre, de que el ayuntamiento fuera de izquierdas e hiciera cumplir la medida ${ }^{70}$, aunque no faltaron casos en los que los miembros de las organizaciones sindicales presionaban al alcalde o al párroco para que estableciera restricciones en el uso de las campanas. En las parroquias de Otívar y Quentar llegó a darse el caso de que unos desconocidos robaran los badajos de las campanas para impedir que éstas tocaran ${ }^{71}$.

\section{Hostigamiento a sacerdotes}

La vida de los sacerdotes dio un incómodo giro durante la Segunda República y la causa no estuvo sólo en la progresiva reducción del presupuesto de culto durante el gobierno de Azaña. Si desde hacía décadas los sacerdotes tuvieron que soportar mal que bien la indiferencia que hacia las cosas de la Iglesia mostraba una parte de la población, ahora tendrán que ver como no sólo el distanciamiento se extiende, sino también como éste iba acompañado de una creciente hostilidad. La situación se irá agravando conforme la oposición de la Iglesia hacia la República y su respaldo a las derechas se vaya haciendo más palpable.

En el anterior capítulo hemos visto como el culto externo fue entorpecido en ocasiones por la legislación laicizadora o por actos anticlericales. El culto en el interior de los templos también sufrió alteraciones. La más usual era la interrupción de una misa por personas que daban voces en la iglesia o se burlaban en la puerta de los que acudian a ella ${ }^{72}$. En Juviles,

68 Ideal, 20 mayo 1932.

69 Ideal, 14 marzo 1933.

7o Lo más frecuente es que el párroco cumpliera la norma, aunque de mal grado, como en Bentarique, Instinción o Dalias, ADG, 190-F/26, 46 y 72.

7. ADG, 190-F/110 y 122.

72 Pueden citarse casos en Escúzar, illora, Ítrabo, La Herradura, Otívar, Torvizcón, La Zubia... ADG. $190-\mathrm{F} / 53,65,70,73,85,110$ y 133. 
por ejemplo, unos individuos arrojaron una piedra contra una ventana cuando se celebraba un bautismo a la vez que alguien se asomó al templo gritando "eso es todo mentira" ${ }^{73}$. Las pintadas y carteles amenazadores en las paredes de los templos eran otro recurso intimidatorio habitual. La colocación de la propia bandera republicana también era considerada por algunos sacerdotes como una agresión ${ }^{74}$. Relato elocuente nos ofrece un sacerdote de Motril de lo que acaecía en esta localidad costera en los últimos meses de la República:

"Aunque con regularidad se venian celebrando los cultos en el interior de los templos, el acceso a ellos por parte de los fieles no era nada grato, puesto que mozalbetes de corta edad, instigados por los trabajadores y colocados en las puertas de las Iglesias, dedicábanse a insultar groseramente a cuantas personas entraban, llegando a adquirir estas bochornosas escenas un carácter más grave los domingos y días de precepto, por la mayor concurrencia de fieles y aumento también de los insultantes, que ya no eran sólo los de corta edad, sino también jóvenes. Como escenario de estos hechos era escogida principalmente la Iglesia Mayor y en menor cuantía las restantes Iglesias",

Esta situación llegó a su culmen en la manifestación del $1^{\circ}$ de mayo de 1936:

"En ese día, desde las primeras horas de la mañana, bandas de jóvenes proletarios uniformados cercaron los templos de la Ciudad, impidieron la celebración de las misas y continuación de los cultos, exigiendo además la inmediata salida de los fieles de las Iglesias y pronta clausura de las mismas. Por la tarde, tuvo lugar una manifestación imponente, llevando infinidad de banderas, uniformadas las juventudes de ambos sexos y a la que concurrian no menos de siete mil personas: al pasar por la Residencia de Padres Agustinos prorrumpieron en mueras y toda clase de gritos subversivos que ya no cesaron hasta el término de la manifestación que se despidió con un mitin amenazador contra la Iglesia y orden social» ${ }^{75}$.

La creciente hositilidad de una parte de la población obligó a muchos sacerdotes a ser cada vez más discretos en el uso de sus atuendos. En un mitin de Acción Nacional celebrado en la plaza de Toros de Granada el lider conservador Gil Robles y el párroco de Dúrcal, Rafael Ponce de León, denunciaron el miedo de muchos sacerdotes a ir por los caminos

\footnotetext{
Testimonio del sacerdote Francisco Martín Soto, ADG, 190-F/78.

Pueden citarse los casos de Beires y Terque, ADG, 190-F/23 y 131.

Testimonio del Sacerdote Salvador Huertas Baena, ADG, 190-F/100.
} 
con sus hábitos ${ }^{76}$. Muy diferente era la opinión de un maestro de Loja, para el cual "era una vergüenza el permitir que los curas llevaran sotana" 77 .

Las ropas de los sacerdotes se prestaron a mofa durante los carnavales de la República ${ }^{78}$. En 1936, por ejemplo, hubo procesiones burlonas contra el clero en las que la gente lució trajes que imitaban las ropas de los religiosos ${ }^{79}$. En Escúzar un grupo de izquierdistas disfrazados de sacerdotes llegó al extremo de simular el entierro de Gil Robles, encarnado por un muñeco que acabó en el fondo de un barranco ${ }^{80}$.

Aunque la integridad física de los sacerdotes no estaba en peligro ${ }^{B 1}$, muchos tuvieron que enfrentarse a un desazonador acoso. Éste solía consistir en insultos, burlas o amenazas ${ }^{82}$. Ante estas situaciones los párrocos poco podían hacer, si bien no faltó quien se encarara con los anticlericales. Ese fue el caso del cura de Huecija, Luis Almécija, localidad en la que con ufrecuencia se celebraban mítines violentos en que el tema más corriente era el ataque a la Iglesia y a las cosas de Dios". El propio sacerdote era víctima de "burlas y canciones", pero "siempre salió al frente de esas provocaciones, con valentía que amedrentaba a los ofensores" ${ }^{83}$. Más belicoso era el sacerdote de Jayena un, al parecer, importante propietario de tierras que se distinguió en dos incidentes. El primero cuando un gitano embriagado fue, navaja en mano, a exigirle unos jornales que le

76 Durante el mitin, celebrado en febrero de 1932, se produjeron enfrentamientos entre derechistas y simpatizantes de la FLSU. Varios anarquistas fueron detenidos. Por la tarde hubo un banquete en homenaje a Gil Robles al que asistieron, además del párroco mencionado, el cura malagueño Andrés Col. Las Juventudes Socialistas emitirán un comunicado lamentando que el Gobernador Civil reprimiera a los obreros porque los verdaderos elementos del desorden fueron "el señorito y la dama catequista" que acudieron en masa al mitin. El Defensor, 1 y 2 marzo 1932.

i7 Testimonio de Cristóbal López e Izquierdo Padilla, ADG, 190-F/87.

78 Como señala Gilmore: "Durante la Segunda República (e incluso antes), la celebración se politizó, convirtiéndose en un pretexto para la violencia y el enfrentamiento". Y añade que "el carnaval siempre ha sido un buen momento para el pronunciamiento social de la comunidad. Apreciado como una licencia para criticar, inculcar o difamar, el carnaval es para la gente corriente de Andalucia un foso para poner las cosas en su sitio de acuerdo con los usos y costumbres de los pobres". GiLmore, D. D., Agresividad y comunidad. Paradojas de la cultura andaluza, Granada, Diputación Provincial, 1995, p. 181.

73 Alomartes y Colomera son dos buenos ejemplos. ADG, 190-F/16 y 43.

30 Testimonio del sacerdote Gaspar Garcia, ADG, 190-F/53.

31 Algunos sacerdotes fueron objetivo para piedras lanzadas por niños, con escasa puntería al parecer. Pueden citarse casos en Alhama, Arenas del Rey, Dúdar, Loja, Órjiva y Pinos Genil. ADG, 190-F/11, 18, 50b, 87, 109 y 115

${ }_{82}$ Aparte de los muchos casos citados en la provincia de Granada, pueden citarse otros de las localidades almerienses que pertenecian a la diócesis de Granada: Alhabia, Alhama de Almeria, Bentarique, Instinción... ADG, 190-F/9, 10, 26 y 72.

83 Los anticlericales de Huécija amenazaban con incendiar la iglesia o convertirla en almacén y fábrica. Testimonio del párroco Alberto Gómez, ADG, 190-F/66. 
debía; el párroco lo redujo golpeándole con un bastón ${ }^{84}$. Meses después unos campesinos quisieron reclamarle otros jornales que les adeudaba, pero el párroco los recibió con dos tiros de escopeta. Por este hecho lo detuvo la guardia civil, aunque el cura quedó en libertad al declarar que los disparos los había efectuado un sobrino suyo que en aquellos momentos estaba con él ${ }^{85}$. Precisamente las denuncias por posesión ilegal de armas constituyeron el motivo, en diversas ocasiones, del registro de casas rectorales por la guardia de asalto ${ }^{86}$.

Muy raros fueron los casos de curas que abandonaran sus parroquias en el primer bienio republicano. Uno fue el de San Nicolás del Mozo, pequeña localidad de la Sierra de Baza. Por razones que no explicita la prensa, durante la celebración de sus fiestas "los vecinos de varios anejos limítrofes se habian reunido, acordando conceder un plazo de 48 horas al cura de San Nicolás, don Manuel López Herrera, para que abandonara la parroquia». La guardia civil intervino "para calmar los ánimos, que estaban muy excitados, y custodió al cura, quien, ante una posible alteración de orden, optó por marcharse a Guadix, calmándose entonces el vecindario" ${ }^{87}$. Otro caso se dio en mayo de 1932 en Lújar al no permitir el párro$\mathrm{co}$, Juan Bazaga Palacios, que la gente del pueblo repicara las campanas con motivo del primer aniversario de la República y, además, por haberse negado a enterrar en sagrado a un niño que sus padres, "destacados ateizantes, no quisieron bautizar". El párroco escapó a media noche del pueblo porque temía que se estuviera fraguando su asesinato ${ }^{88}$.

En los últimos meses de la República numerosos curas fueron hostigados con el evidente objetivo de que su vida se tornara tan incómoda e insegura que al final optaran por marcharse del pueblo por su propio pie. En algunas ocasiones los anticlericales se mostraban más impacientes y recurrían a piquetes que se presentaban amenazantes en la casa parroquial. En Fuente Vaqueros, por ejemplo, fue una "turba de mujerzuelas" la que obligó al sacerdote a ausentarse de la localidad ${ }^{89}$. Más frecuente eran los grupos de jóvenes organizados, caso de Gualchos, Lújar y Güejar Sierra.

84 El Defensor, 31 diciembre 1931

85 Ideal, 15 mayo 1932.

86 A finales de septiembre de 1933 el párroco de la localidad de Pedro Martínez fue detenido durante veintiséis horas por posesión de armas. El hecho fue denunciado por militantes socialistas que cachearon a algunos fieles y les hallaron cuatro pistolas. La guardia civil impidió que se produjeran más cacheos y cerró temporalmente el templo (/deal, 19 septiembre 1933). Otros casos (Quentar y Tocón) datan ya de la primavera de 1936. ADG, 190-F/122 y 133.

8т El Defensor, 22 agosto 1931.

88 ADG, 190-F/89.

89 Testimonio del sacerdote Miguel Ríos, ADG, 190-F/58. 
De esta última localidad fueron expulsados dos sacerdotes en poco tiempo, tal y como relata uno de ellos:

"A los pocos días de ausentarse el párroco D. Guarnido Sarvi, el cura que suscribe tomó posesión del curato en medio del silencio hostil de los grupos marxistas que había distribuidos cerca del templo. En la misma tarde, a pocas horas de la toma de posesión, fue amenazado verbalmente por dos jóvenes marxistas, y conminado a abandonar el pueblo antes que llegara la noche. A las doce y media de la noche fue obligado a levantarse del lecho, y hubo de prometer que abandonaría el pueblo cuando fuese de día, como lo verificó, sin que lo inquietaran al salir del mismo. Este incidente ocurrió el día dos de abril de 1936. Desde esa fecha estuvo clausurado el templo parroquial. [...] El pueblo católico no se atrevió a protestar, ni a pedir que se abriera la iglesia” ${ }^{90}$.

Algunas expulsiones estuvieron precedidas de amenazas irónicas, como la que un grupo de personas protagonizó el 31 de mayo en Lújar al sacar las imágenes de la parroquia y colocarlas formando una procesión que salía del pueblo. Al día siguiente los izquierdistas se personaron en el domicilio del párroco y lo expulsaron de la localidad ${ }^{91}$.

Además de los casos ya citados, tenemos noticias de que fueron clausuradas las parroquias o expulsados los sacerdotes en Albondón, Alomartes, Asquerosa, Benalúa de las Villas, Berja, Busquistar, Castell de Ferro, Cenes de la Vega, Deifontes, Guadahortuna, illora, Iznalloz, Láchar, Nacimiento, Ogíjares, Pinos Genil, Pinos Puente, Puebla de Don Fabrique y Rubite. La mayoría de los cierres y abandonos se produjeron a partir de mayo de 1936, al calor del triunfo izquierdista en la repetición de las elecciones. Hay que mencionar también a los curas encarcelados, nunca por plazos superiores a tres días, en Algarinejo, Dílar, Tocón, TorreCardela y Zagra.

La expulsión de los sacerdotes implicaba la clausura del templo, que permanecía bajo llave a la espera de mejores tiempos para el catolicismo. No obstante, hubo casos en los que organizaciones izquierdistas intentaron incautarse de los edificios religiosos. Estos intentos secularizadores fueron muy raros, aunque son significativos porque revelan un deseo "desamortizador" que se manifestará con espontaneidad nada más iniciarse la Guerra Civil. Demuestran también que para muchos izquierdistas los edificios religiosos estaban llamados a servir a fines públicos más que a perecer en incendios.

90 Testimonio del sacerdote Manuel Montes Montero, ADG, 190-F/64.

91 AHN, Sección Causa General de Granada leg. 1041 a 1043. 
A finales de 1933 en Vélez de Benaudalla elementos izquierdistas aprovecharon una ausencia del párroco para incautarse de la casa rectoral con el objeto de dedicarla a escuela pública ${ }^{92}$. En Guajar Alto, aunque la casa rectoral estaba habitada por un particular que hacia servicios a la parroquia, los militantes socialistas procedieron a su ocupación ${ }^{93}$. En Lobras, según el párroco, el Ayuntamiento se apropió de la casa rectoral para instalar un centro obrero de la UGT ${ }^{94}$. Las Juventudes Libertarias de Quentar, por su parte, quisieron instalar su sede en la sacristia de la iglesia, pero la oposición del párroco les llevó a apoderarse, tras el derribo de una pared, de la sacristía de la ermita de San Sebastián ${ }^{95}$. Menos suerte tuvieron los izquierdistas en Berja, donde fracasaron en su intento de convertir en Casa de Socorro una de las dependencias del templo ${ }^{96}$.

Los conventos también sufrieron el acoso anticlerical y no faltaron frailes y monjas que evacuaran sus residencias por temor a males mayores. Casi todos los abandonos fueron temporales y coincidieron con explosiones anticleriales como la de mayo de 1931. También hubo mudanzas definitivas, como la de las monjas del Ángel Custodio de Granada, que dejaron su convento de la Gran Vía cansadas de que durante las manifestaciones obreras se las amenazara con consignas anticlericales. Según la abadesa, vivian "en un continuo sobresalto y gran inquietud de día y de noche" y al final prefirieron trasladarse a la antigua sede del Banco de España, situada en la tranquila calle de San Antón ${ }^{97}$.

Los franciscanos del convento de la Piedad de Baza abandonaron la ciudad por un suceso confuso ${ }^{98}$. Pero el caso más espectacular de expulsión de unas monjas fue el que se dio con el convento de Santa Clara de Alhama. Según nos relata sor Sacramento Pérez:

«El día 16 de marzo de 1936, a las dos de la tarde, presentáronse en nuestro convento cuatro guardias de Asalto, enviados por las autoridades del pueblo, con objeto de practicar un registro, pues se decía que teníamos escondidas dentro de la clausura armas de varios señores derechistas. Todo lo peor de la población se situó en las inmediaciones del convento, dando

92 Testimonio del sacerdote Antonio Barea Molina, ADG, 190-F/140.

93 Testimonio del sacerdote Rafael $F$. Vázquez, ADG, 190-F/59b.

94 Testimonio del sacerdote Francisco Martín Soto, ADG, 190-F/86.

95 Testimonio del sacerdote Manuel López Díaz, ADG, 190-F/122.

96 ADG, 190-F/28.

97 La abadesa sor María Aurora Pérez declaró que en varias ocasiones tuvieron "que salir de la clausura entre el clamor de las turbas exaltadas" que amenazaban con prender fuego al convento. ARACIL, Dolor y triunfo. Héroes y mártires en pueblos de Andalucía durante el alzamiento nacional, Barcelona, Tipografia Católica Casals, 1944, p. 376.

98 El Noticiero Granadino, 25 marzo 1936. 
golpes a las puertas y gritando: ¡Fuera las monjas! $Y$ diciendo otras mil barbaridades $[\ldots]$.

«En estos angustiosos momentos, seis jóvenes de la peor calaña saltaron las tapias del jardín y abrieron la puerta, e inmediatamente penetraron en el interior muchos rojos, entre los cuales habia muchas mujeres. Como locos comenzaron a correr de acá para allá, dedicándose algunos a vaciar los estanques y pilas de agua, a fin de que no se pudiera extinguir el fuego que pusieron en el dormitorio".

Las monjas tuvieron que abandonar finalmente el convento escoltadas por los guardias de asalto mientras los anticlericales las cinjuriaban con cantos impíos". A continuación el convento fue saqueado hasta el extremo de robar las plantas del jardín ${ }^{99}$.

\section{Iconoclastia}

La desacralización de las calles fue una tarea llevada a cabo con singular rigor durante la revolución burguesa, un siglo antes de la Segunda República. La apariencia de ciudades y pueblos se transfiguró al desaparecer una parte importante de las hornacinas, cruces y conventos ${ }^{100}$. La Restauración alfonsina supuso un cierto retroceso en este camino, aunque no demasiado importante. De todas formas, al proclamarse la Segunda República todavía eran numerosos los elementos que sacralizaban rincones de las ciudades y caminos. Las autoridades encargadas de dar nuevos pasos a favor de la laicización serán, al igual que un siglo atrás, las municipales. Lógicamente sólo los ayuntamientos con mayoria de izquierdas adoptaron medidas en este sentido, como la retirada de cruces o el cambio de nombre de calles y plazas ${ }^{101}$.

En cualquier caso, las repercusiones de la laicización impulsada por las autoridades fueron mínimas. Los izquierdistas anticlericales serán los

99 Aracil, op. cit., pp. 376 a 377 . Testimonio corroborado por el párroco Gaspar García, ADG, $190-F / 53$,

100 Barrios Rozúa, Reforma urbana..., op. cit., pp. 162 a 164 y 240 a 243.

101 A veces se quiso ver actitudes anticlericales donde realmente no las había. Un ejemplo es la polémica suscitada en Granada por la intención del Ayuntamiento de trasladar la estatua de fray Luis de Granada desde la plaza de Bibarrambla a otra más pequeña y colocar en su lugar una fuente. Esto fue considerado por la derecha como un acto anticlerical. Curiosamente, fue el alcalde Antonio Gallego Burín el que en 1940 trasladó la escultura (El Defensor, 18 octubre 1931). Otro caso en el que el anticlericalismo es producto de una imaginación paranoide se dio en Guadix, donde un párroco consideró como acto de "persecución de la lglesia" la colocación de una torreta de la luz junto al templo de Santiago (/deal, 3 agosto 1932). 
que asuman por su cuenta la completa desacralización de los espacios urbanos mediante la comisión de actos violentos, unas veces planificados, otras espontáneos, que llevaron a cabo siempre al margen de la legalidad. En los atentados cometidos contra bienes religiosos pueden distinguirse varias modalidades según el grado de planificación y su carácter destructivo.

Los elementos más vulnerables, como cruces y hornacinas, fueron objetivos preferentes y fáciles de destruir. Las cruces eran derribadas casi siempre en acciones premeditadas que llevaban a cabo grupos reducidos de personas que mediante una soga anudada al extremo superior de la cruz tiraban de ella aprovechando alguna noche tranquila. En cuanto a las hornacinas, una certera pedrada podia acabar con la imagen y el cristal que la protegía.

Los templos y conventos sufrieron ataques muy diversos en su factura y consecuencias. Los atentados cometidos mediante petardos, casi siempre llevados a cabo por grupos bien organizados de faístas, rara vez ocasionaban daños de alguna importancia. Los petardos eran unos artefactos de fabricación casera compuestos, normalmente, por un cilindro metálico relleno con un explosivo que detonaba una mecha. Pocos de ellos podían calificarse de bombas y nunca se utilizaron contra personas, por lo que puede afirmarse que su intención era más psicológica que destructiva. $\mathrm{Pa}$ recida función a los petardos tenían los conatos de incendio provocados al rociar con gasolina una puerta o una ventana; aunque el fuego nunca prosperaba, sí que podía dar un buen susto.

Más grave era cuando los anticlericales penetraban durante una protesta en el interior de un edificio eclesiástico. Los desperfectos estaban entonces garantizados, aunque si el acto era espontáneo, pocas veces aspiraban a destruir el inmueble. Los asaltos más peligrosos fueron los premeditados. Los atacantes seguian en estas ocasiones un guión que rara vez presentaba novedades: forzaban la puerta con hachas $u$ otros elementos conturidentes, amontonaban todos los objetos combustibles (bancos, imágenes de madera, lienzos...) en el centro del templo, los rociaban con gasolina y les prendian fuego. En estas circunstancias sólo una rápida intervención de la fuerza pública y los bomberos podia evitar la destrucción del edificio.

Los incidentes iconoclastas, aunque habian tenido algún precedente en los últimos años de la Dictadura, crecieron exponencialmente desde la proclamación de la República. Uno de los primeros incidentes se produjo en La Zubia, localidad de población mayoritariamente socialista, la entrada de la primera junta gestora municipal estuvo acompañada de una manifestación 
con numerosos jóvenes vinculados a la casa del pueblo. Éstos asaltaron el Ayuntamiento entre gritos contra el clero y quemaron los retratos de los reyes, de un militar de la localidad y del arzobispo Salvador de Reyes y García de Lara, o sea, de todas las personas que de una u otra manera encarnaban la extinta monarquía ${ }^{102}$.

La dinámica de asaltos contra edificios religiosos arrancará con los graves incidentes iniciados el 10 de mayo de 1931. El detonante de la célebre "quema de conventos» será una provocadora reunión del club monárquico de Madrid. Numerosos conventos ardieron en la capital aquella noche; al día siguiente los disturbios se extendieron por varias ciudades. En Granada nutridos grupos de personas asaltaron el colegio de padres Maristas y los conventos de Agustinos y de Comendadoras de Santiago; además, una bomba estalló en el convento de Carmelitas Calzadas. Al dia siguiente fueron atacadas la iglesia del Corazón de Jesús, el centro católico Casa de los Luises, la Residencia de Redentoristas y el convento de Capuchinos. En la provincia sería saqueada la iglesia parroquial de Maracena y hubo un conato de incendio en el convento de Santa Clara de Loja ${ }^{103}$.

Todos estos incidentes, aunque no revistieron daños de importancia, provocaron el pánico de las monjas, que abandonaron los conventos para trasladarse a los domicilios de familiares. Pero aún más ilustrativo del temor generado por los incidentes es lo ocurrido en Atarfe el día 16 de mayo. A esta localidad llegó la noticia de que unos individuos que se desplazaban en coche a Santa Fe habian intentado quemar la iglesia del convento de monjas jesuitinas. El temor de algunos vecinos de Atarfe a que esos mismos incendiarios pudieran hacer lo propio con la iglesia de su pueblo les llevó a montar un piquete. Un ingeniero que se desplazaba con su familia se atemorizó al verlo, pensando que eran delincuentes o revolucionarios. Lo arrolló con su vehículo y se estrelló a continuación, con el trágico balance de cuatro muertos, tres obreros y la hija del ingeniero, además de numerosos heridos ${ }^{104}$.

Durante los meses siguientes Granada se verá sacudida por una elevada conflictividad obrera debida a las difíciles condiciones de los asalariados, los altos índices de desempleo y la intransigencia de los empresarios. Las

102 Fue destruido también un antiguo y valioso estandarte del pueblo. ADG, 190-F/85.

103 El Defensor, 14 mayo 1931 y ADG, 190-F/s/n. La iglesia de Maracena volveria a ser objeto de un atentado dos años más tarde, cuando fue incendiada con gasolina su puerta, Ideal, 25 abril 1933.

104 El mismo día fueron detenidas cinco personas como sospechosas del incendio de Santa $\mathrm{Fe}$, que habia causado daños de poca importancia. El Defensor, 17 mayo 1931 
numerosas y combativas huelgas convocadas por la CNT fueron duramente reprimidas muchas veces por la fuerza pública, ocasionando algunas víctimas mortales. Este escabroso escenario fue aprovechado por grupos radicales, presumiblemente vinculados a la FAI y a las Juventudes Libertarias, para realizar numerosos ataques con petardos contra domicilios de derechistas, centros conservadores y edificios de la Iglesia. Fueron objeto de atentados en diferentes fechas la iglesia de San Cecilio, la iglesia de San José, el palacio Arzobispal, la iglesia de Santa Ana y el convento de la Presentación. La mayoría no ocasionaron daños reseñables.

El intento de golpe de Estado iniciado por el general monárquico Sanjurjo el 10 de agosto de 1932 fue el desencadenante de graves disturbios en la ciudad de Granada: intento de asalto al diario católico /deal, incendio del Casino y del colegio Divina Infantita, ataques sin consecuencias contra el centro católico Casa del Estudiante, el convento de Trinitarias, el convento de Tomasas, el convento de Santa Paula, la iglesia de San Luis y la completa destrucción de la iglesia de San Nicolás ${ }^{105}$.

La Sanjurjada tuvo también repercusiones en la provincia. El hecho más grave ocurrió en Escóznar el 11 de agosto, día en el que elementos izquierdistas asaltaron el templo y, además de causar graves daños en él, hicieron mofa de los ornamentos destinados al culto por calles y plazas de la localidad. La iglesia quedaría cerrada a partir de esa fecha y las misas y otros actos religiosos tuvieron que celebrarse en una casa particular habilitada para capilla ${ }^{106}$. En Guadahortuna la guardia civil consiguió evitar la destrucción de la iglesia parroquial, mientras que en Alfacar fue incendiado el cortijo del conde de Guadiana, uno de los cabecillas del golpe de Estado, en cuya capilla se conservaban algunas imágenes religiosas ${ }^{107}$.

En Churriana la iconoclastia amenazó con borrar de las calles cualquier rastro del catolicismo. En una crónica enviada al Ideal en 1932, el párroco lamentaba que su pueblo sufriera sucesos anticlericales "análogos a los que vienen ocurriendo en otros varios pueblos»:

"Los primeros accidentes habidos fueron en las fiestas celebradas el día 8 de septiembre pasado, al terminar la procesión que se celebró con todo orden. Un grupo de extremistas se dirigió a la Cruz que existía en la plaza

105 Detallados relatos de estos incidentes pueden verse en BARRIOS ROzÚA, “Conflictividad social...", op. cit., pp. 197 a 201 y VIÑES MILLET, C., “Los sucesos de agosto de 1932 en Granada. Fuerzas locales y tensiones politicas", Hispania, 156 (1984), pp. 107 a 136.

106 En el asalto resultaron destruidas casi todas las imágenes y ornamentos del templo. ADG, $190-\mathrm{F} / 52$.

10. El Defensor, 13 agosto 1932 e /deal, 15 septiembre 1932. 
del Altozano, haciendo contra la misma varios disparos y consiguiendo luego derribarla por completo [...].

"En la noche del domingo pasado, los elementos extremistas de pueblos distintos tuvieron una reunión [...]. Parece que desde entonces se han intensificado más los atentados contra la Religión, pues el lunes pasado varios de estos extremistas se dirigieron al Ayuntamiento en cuya fachada había una placa del Sagrado Corazón de Jesús, y que destrozaron por completo [...]. Desde la plaza del Ayuntamiento se dirigieron los grupos a la Ermita de la Virgen de la Cabeza, con intención de derribar las tres cruces que hay frente a la misma y en las cuales termina el Via Crucis, pero no lo consiguieron por haberse opuesto el sacristán [...].

"En la noche del dia 19 fue destrozada, igualmente, otra placa del Sagrado Corazón que daba el nombre a la plaza donde se hallaba.

"Todos estos tuvieron mayor importancia en la madrugada del 20 al 21 en la que, un grupo mayor, se dedicó sin el escrúpulo de ocultar sus hazañas a los vecinos, ni la menor oposición de las autoridades, a derribar ocho cruces de las que forman el Vía Crucis, del cual sólo quedan en pie cuatro, ya que las otras fueron derribadas hace más tiempo, una de ellas por una yunta de bueyes, y la otra por accidente del tiempo.

"También ha sido derribada otra Cruz que por su cuenta construyó el vecino don Manuel Sánchez Álvarez [...]. En varias casas, en cuya puerta o fachada existía alguna imagen, las han tenido que retirar ante las amenazas de los mismos sujetos" ${ }^{108}$.

A finales de 1932 la detención del lider anarcosindicalista Fernando Maroto ocasionó huelgas y protestas en Granada, incluida la colocación de petardos en los conventos de Santa Paula y de Zafra, amén de varios domicilios y negocios de derechistas. Meses después fueron socialistas los que tras un mitin celebrado en Salar, en el que hubo acres palabras contra el arzobispo por haber excomulgado al diputado Luis López Dóriga, destruyeron imágenes expuestas en las hornacinas de algunas casas ${ }^{109}$.

Numerosas cruces desaparecieron en acciones planificadas y llevadas a cabo por grupos izquierdistas. En Granada fueron personas de adscripción anarquista las que a lo largo de tres noches en septiembre de 1932 derribaron buena parte de las cruces de la ciudad. El ejemplo fue imitado meses más tarde por los miembros de las Juventudes Socialistas de íllora, que derribaron durante tres madrugadas consecutivas las cruces de piedra

108 Por estos incidentes la guardia civil detuvo en Churriana a Francisco Pascasio Martín; otras tres personas lograron darse a la fuga. Ideal, 23 y 27 octubre 1932.

109 López Dóriga era sobrino del arzobispo José Meseguer y Costa y llegó a ocupar un alto cargo en el Cabildo de la Catedral. Su excomunión demostraba la dificultad, a los ojos de la jerarquia, de ser izquierdista y católico. Ideal, 24 marzo 1933. 
llamadas de San Pedro y del Convento, e intentaron lo mismo con la conocida como del Padre Joaquín ${ }^{110}$. También debió ser un acto planeado la destrucción de una cruz del artesano neobarroco Navas Parejo colocada en el puente de los Caños (Lanjarón) como homenaje a un padre agustino ${ }^{111}$.

No siempre la destrucción de cruces era fruto de atentados cometidos con nocturnidad. En Atarfe, Alfacar, La Zubia y otras localidades fueron las autoridades municipales las que decidieron la desaparición de las cruces porque «en un régimen laico no deben permitirse en la vía pública insignias de ninguna religión" ${ }^{112}$. En La Zubia fue derribada por decisión municipal la cruz de San Antón al son del himno de Riego. Más tarde le llegaría el turno a la gran cruz ubicada en la placeta de la ermita de San Pedro y a otras cuatro cruces situadas junto a la ermita del Calvario ${ }^{113}$.

En la localidad de Salar un grupo de vecinos, "con el beneplácito de la mayor parte del pueblo", derribó con una soga la cruz que había en la puerta de la iglesia y la arrastraron por el pueblo hasta destrozarla por completo. Después, provistos de palancas, causaron daños en el templo, al que días antes habían arrancado la verja ${ }^{114}$.

El año 1933 se abrió con la segunda de las insurrecciones promovida por los faístas durante la República. Los únicos incidentes reseñables en Granada fueron la explosión de petardos en la parroquia granadina de San Matías y en el taller de imaginería religiosa de Navas Parejo. En los meses siguientes hubo conatos de incendio en los templos de La Zubia y Vélez de Benaudalla, aunque ninguno de ellos prosperó gracias a la intervención de vecinos católicos ${ }^{115}$.

Un asunto que en numerosas ocasiones sale a colación, pero del que siempre se habla genéricamente, es el de los incendios de iglesias provocados por derechistas para incitar la represión sobre el movimiento obrero. Esta fue una justificación a la que los republicanos acudieron en numerosas

110 Destacaba por śu antigüedad y calidad la cruz de San Pedro. Testimonio del sacerdote Francisco López Luque, ADG, 190-F/70 e Ideal, 28, 29 y 30 abril 1933.

111 Ideal, 26 octubre 1932.

112 En Atarfe los restos de las cruces se utilizaron para hacer bordillos de las calles, incluida una valiosa cruz que tenía esculpido un relieve que representaba a Cristo con la cruz a cuestas. Ideal, 25 y 28 octubre 1932 y 12 abril 1933, y ADG, 190-F/7.

${ }_{113}$ La cruz más antigua, con tres siglos de antigüedad, era la de San Antón. Estos derribos y un incendio provocado que afectó a la entrada de la iglesia llevaron a tomar la precaución de desmontar y guardar en la parroquia la Cruz de Misión que había adosada a uno de sus muros. Los restos de las demás cruces quedaron esparcidos por el suelo durante toda la República. ADG, $190-F / 85$.

114 Ideal, 4 octubre 1933.

115 ADG, $190-\mathrm{F} / 85$ y 140 . 
ocasiones durante y después de la Guerra Civil para explicar unas destrucciones del patrimonio histórico de las que se sentían avergonzados. Como explicación global no es válida, pero sí es cierto que hubo algunos casos en la provincia de Granada. Lo que no es posible determinar es cuántos, bien porque el grueso de las fuentes de información están vinculadas a la Iglesia y a las derechas, bien porque en la mayoría de los casos no se descubrió a los autores. No obstante, pueden citarse dos episodios, uno en Guadahortuna, ya a finales de la República y que veremos más adelante, y otro en Atarfe. Éste se produjo el 22 de noviembre de 1933, cuando se declaró un pequeño incendio en la puerta de la iglesia. ldeal se apresuró, sin pruebas, a imputarlo a las Juventudes Socialistas. Éstas replicaron enviando una indignada nota al periódico en la que acusaban a los derechistas de haberlo provocado con la intención de que se desatara la represión contra las gentes de izquierdas aprovechando el reciente triunfo conservador en las elecciones, y añadian que la "clase trabajadora de Atarfe sabe su deber, no gasta sus fuerzas inútilmente para cosas de tan poca monta como el hecho de quemar una iglesia» ${ }^{116}$.

El 8 de diciembre, día previsto para la apertura de las Cortes, comenzó la última de las insurrecciones anarquistas, que fue también la de mayores repercusiones en la provincia de Granada, sin duda por la crispación creada por la reciente campaña electoral y el triunfo de las derechas. Esta insurrección provocó hechos especialmente graves en la capital, donde hubo conatos de incendio de diversa importancia en el convento de Santa Inés, iglesia de San José, beaterio de Recogidas, iglesia de San Gregorio Alto, iglesia de San Cristóbal, sacristía de la parroquia de El Salvador y ermita del Santo Cristo de la Yedra. Pero lo más grave fue el asalto y completa destrucción que sufrieron el templo de San Luis y el convento de Tomasas.

La insurrección tuvo también algunas repercusiones en localidades de la provincia: en Atarfe cuatro menores con edades de doce y trece años intentaron prender fuego a la iglesia parroquial del pueblo; en Huétor Vega varios individuos quemaron la puerta de la sacristía de la iglesia ${ }^{117}$; en Dúrcal un grupo de personas destrozó una cruz echándola abajo ${ }^{118}$; en Huéscar fue destruido a martillazos un cuadro de la Virgen María guardado en el Ayuntamiento ${ }^{119}$; en Iznalloz fueron detenidos dos hombres por

116 ldeal, 23 y 26 noviembre 1933.

117 Ideal, 13 diciembre 1933.

118 El Defensor, 13 diciembre 1933

119 El cuadro era, según parece, de cierta calidad. Ideal, 15 diciembre 1933 
lanzar piedras y dañar una antigua hornacina sita en una plaza ${ }^{120}$; y en Albolote la guardia civil detuvo a siete personas por cortar los hilos telefónicos y planear el incendio de la iglesia parroquial ${ }^{121}$.

La dura represión que se vivirá en la provincia a partir de la victoria de las derechas, con el encarcelamiento masivo de miembros del movimiento obrero, el cierre de sus sedes políticas, la destitución de los ayuntamientos de izquierdas y la permanente proclamación de estados de emergencia, impedirá la comisión de actos anticlericales. El único incidente del que tenemos constancia ocurrió en junio de 1934, cuando la tensión provocada por la huelga campesina que se desarrolló aquel verano llevó a un grupo de niños y jóvenes a saquear la ermita del cementerio que los jesuitas tenian en la Cartuja.

La calma del "bienio negro" fue un falso "orden social» que creó las condiciones de futuras explosiones iconoclastas al radicalizar y extender el anticlericalismo en el movimiento obrero. Después de las elecciones de febrero de 1936 -anuladas en la provincia por el fraude promovido por el Bloque Contrarrevolucionario- los sucesos anticlericales se multiplicaron.

Entre las víctimas más destacadas de la espiral de violencia que se viva en estos últimos meses de la República estarán los templos parroquiales, convertidos en los centros más significativos de las derechas. En los momentos de mayor tensión fueron custodiados por las fuerzas de orden público ${ }^{122}$, por vecinos católicos ${ }^{123}$ e incluso por militantes de la izquierda que no querían que se diera pie a medidas represivas de la guardia civil ${ }^{124}$. Pese a estas protecciones ocasionales, los templos siguieron siendo extremadamente vulnerables.

Los incidentes más graves de este periodo ocurrieron en Granada a raíz de un agresión contra obreros por parte de pistoleros falangistas. En respuesta convocaron las organizaciones obreras una huelga general para el día 10 de marzo durante la cual elementos incontrolados atacaron, además de diversos centros derechistas, la iglesia de San Gregorio Bético, el convento de Santa Inés y las iglesias de San Juan de los Reyes y San

120 Ideal, 13 diciembre 1933 y El Defensor, 13 diciembre 1933.

121 El Defensor, los detenidos acusaron a la guardia civil de haberles torturado para que se autoinculparan. Fueron condenados cuatro de los encausados.

122 JACKSON, op. cit, p. 168.

123 Puede citarse el caso de La Herradura. ADG, 190-F/65.

124 En Granada, por ejemplo, miembros de las Juventudes Socialistas custodiaron algunas iglesias y conventos después de los graves incidentes de marzo. La Publicidad, 15 marzo 1936. 
Cristóbal. Destruyeron por completo la sede del diario católico /deal y la parroquia de El Salvador, la principal iglesia del Albaicín ${ }^{125}$.

No menos graves fueron los disturbios que vivió la Puebla de Don Fabrique el 21 de mayo. Tras un duro enfrentamiento con la guardia civil en el que falleció un miembro de este cuerpo y dos más resultaron heridos, los izquierdistas atacaron la iglesia parroquial, las ermitas de San Antón, la Soledad, el Ángel, San José y los templos de los anexos de Almaciles, Toscana, Bujijar y Los Santos, además de varios edificios vinculados a derechistas ${ }^{126}$.

Los demás incidentes con alguna derivación anticlerical que se vivieron en las diócesis de Granada y Guadix-Baza tuvieron bastante menos importancia. Pocos fueron los intentos de destruir por completo una iglesia y la mayoría de los que se llevaron a cabo fracasaron. Es el caso de los dos conatos de incendio que sufrió el templo de Salobreña ${ }^{127}$ o el que afectó a la iglesia parroquial de Lanjarón, en el que unos individuos perforaron el tejado y lanzaron al interior una mecha de esparto con gasolina provocando un pequeño incendio sin consecuencias ${ }^{128}$. Sí resultó completamente destruida la parroquia de Rubite, única localidad con alcalde comunista, pese a los esfuerzos de algunos vecinos por sofocarlo ${ }^{129}$.

Las imágenes, más que los edificios, eran el principal objetivo de los ataques. La madrugada del 11 de junio varios izquierdistas de Guajar Fondón sacaron esculturas de la iglesia con el ánimo de desalojar el templo. Un grupo de vecinos denunció indignado el hecho a la guardia civil, que se encontraba incidentalmente en la vecina localidad de Guajar Faraguit, la cual detuvo y encarceló a los anticlericales durante unos dias ${ }^{130}$. En Órjiva perecieron las imágenes de la ermita de las Ánimas, algunas de las cuales fueron arrastradas e incluso "ahorcadas" ${ }^{131}$.

En íllora un grupo de personas violentaron las puertas de la parroquia y de la sacristía y formaron con todos los objetos, imágenes y cuadros que

125 El más completo estudio de estos incidentes puede verse en Gu Bracero, Guerra civil en Granada, 1936-1939, Tesis Doctoral, Universidad de Granada, pp. 230 a 237.

126 También fueron incendiados un taller de carpintería y una casa particular. AHN, Sección Causa General de Granada leg. 1041 a 1043.

127 Testimonio del sacerdote Antonio Morales Moreno, ADG, 190-F/126.

128 ADG, 190-F/81.

129 Esta era la única localidad de la provincia de Granada con alcalde comunista. Los sucesos acaecieron el 12 de julio. Los bienes muebles que albergaba carecian de interés artístico según opinión del sacerdote Antonio Jiménez, ADG, 190-F/124.

130 ADG, 190.F/61.

131 ADG, 190-F/109. 
encontraron una gran pira en la plaza. «El Sagrario fue profanado rompiendo su puerta con un hacha y arrojando al suelo y pisoteando las Sagradas Formas». En el templo, además de sus imágenes, se guardaban las del antiguo convento de San Pedro de Alcántara, que era propiedad del Ayuntamiento desde las desamortizaciones. El párroco asegura que "la destrucción y quema de las imágenes y objetos de culto fue realizada en presencia de las autoridades y a los acordes del Himno de Riego tocado por la banda Municipal de este pueblo, a la que acompañaban las hordas con grandes palmas de júbilo y gritos salvajes". La iglesia quedaria clausurada, aunque el párroco celebraría muy discretamente dos misas, una en la sacristía y otra en una casa particular ${ }^{132}$.

En Castell de Ferro un grupo de jóvenes asaltó la iglesia y la casa rectoral destruyendo las imágenes y el archivo. El templo quedaría cerrado. Según denuncia del párroco, los asaltantes fueron miembros de las Juventudes Socialistas liderados por el médico de la localidad Laureano Vázquez ${ }^{133}$. También pertenecian a esa organización juvenil las personas que asaltaron la iglesia de Asquerosa, quemaron sus imágenes y obligaron a clausurarla ${ }^{134}$.

El párroco de Iznalloz relata que uel día 22 de abril fue asaltada la iglesia por el elemento obrero de esta localidad incendiando y destruyendo imágenes y altares, así como gran cantidad de ornamentos sagrados, distinguiéndose en este acto de vandalismo con más saña, las mujeres». Todo ocurrió a media noche y no pudo salvarse nada de las llamas. A pesar de que no hubo detenidos por este hecho, las autoridades franquistas atribuirán años después este episodio a la Sociedad Obrera "El Progreso», afecta a la UGT, y a todos los elementos izquierdistas del pueblo ${ }^{135}$.

El sacerdote de Varadero (puerto de Motril) también acusa a los socialistas de esa localidad, capitaneados por un tal "Aguarrás", de ser los que una noche asaltaron la iglesia de Nuestra Señora del Carmen y destrozaron el Altar, bancos, púlpitos, etc. Sólo se salvó una imagen de la Virgen que una vecina recogió de los escombros ${ }^{136}$. También en Alomartes un enfrentamiento de los socialistas con los caciques y la guardia civil tras la

132 Los sucesos acaecieron el 22 de abril. Algunos de los objetos destruidos eran de especial valor, como un retablo de Pedro Machuca y varias esculturas de madera. Testimonio del sacerdote Francisco López Luque, ADG, 190-F/70.

133 En el asalto resultó destruido el retablo, el archivo y las imágenes, las cuales acabaron flotando en el mar. Desaparecieron por robo el armonio, las campanas y los ornamentos sagrados. ADG, $190-F / 39$.

134 ADG, $190-F / 20$.

135 ADG, 190-F/74 y AHN, Sección Causa General de Granada, leg. 1041 a 1043.

136 El incidente ocurrió el 24 de abril. Testimonio del sacerdote Salvador Huertas Baena, ADG, $190-F / 100$. 
manifestación del Primero de Mayo degeneró en el saqueo de la iglesia. El templo quedó cerrado durante los meses siguientes ${ }^{137}$.

Cariz de broma irreverente tuvo lo que ocurrió en Pinos Genil, donde una docena de individuos forzó la puerta de la iglesia, improvisó unos espantajos con el bonete del párroco, las sotanas de los acólitos y una escobas, encendió todas las velas del templo y se dedicó a fumar durante varias horas ${ }^{138}$.

Uno de los hechos más llamativos fue el que acaeció el 5 de mayo en Guadahortuna, donde los agrarios y el párroco de Guadahortuna retiraron durante una noche los objetos de mayor valor de la parroquia para denunciar al día siguiente que ésta había sido robada. Descubierto el enredo, el Gobernador Civil impuso una multa al centro agrario y al sacerdote. Indignados por estas maquinaciones, los vecinos asaltaron la iglesia, destrozaron algunas imágenes y forzaron su cierre ${ }^{139}$.

También fueron numerosos los ataques contra cruces y hornacinas durante los últimos meses previos a la Guerra Civil. El 19 de marzo tres izquierdistas arrancaron una cruz de madera situada en la fachada de la parroquia de Dúdar y la quemaron ${ }^{140}$. No tuvieron mejor suerte las cruces de Salobreña, las cuales amanecieron el 14 de abril destruidas y sus restos distribuidos entre la puerta de la casa del coadjutor y la del párroco. También fueron retiradas todas las imágenes religiosas que había en las calles de aquella localidad ${ }^{141}$. En Alomartes fue derribada la cruz de piedra que se levantaba en el centro del pueblo y los trozos de ella sirvieron como trancos en las puertas de algunas casas ${ }^{142}$.

El 27 de abril de 1936 eran derribadas de madrugada todas las cruces de Motril, entre ellas algunas antiguas, como las de Capuchinos, del Carmen, de la Aurora y del Cerro de la Cabeza ${ }^{143}$. El 3 de mayo, día de la repetición de las elecciones, le tocó el turno al via crucis de Otívar ${ }^{144}$. Igual suerte corrieron en Pinos Genil la cruz situada en el cerro del Pico del Gallo ${ }^{145}$ y en Órjiva todas las cruces que ornaban algunas de sus calles ${ }^{146}$.

137 LOPEz MARTínez, op. cit., pp. 489 y 490 , y ADG, 190-F/16.

138 Testimonio del sacerdote L. Almecija Ramírez, ADG, 190-F/115.

139 López Martinez, op. cit., pp. 489-490 y AHN, Sección Causa General de Granada, leg. 1041 a 1043

140 Testimonio del sacerdote Manuel López Díaz, ADG, 190-F/50b.

141 Testimonio del sacerdote Antonio Morales Moreno, ADG, 190-F/126.

142 LóPEz MARTINEz, op. cit., pp. 489-490 y ADG, 190-F/16.

143 Testimonio del sacerdote Salvador Huertas Baena, ADG, 190-F/100.

144 Testimonio del sacerdote Guillermo Benavides, ADG, 190-F/110.

145 Testimonio del sacerdote L. Almecija Ramirez, ADG, 190-F/115.

146 ADG, 190-F/109. 
En Güejar Sierra «quitaron los jóvenes marxistas los santos de las hornacinas en las fachadas de las casas particulares, y destruyeron la cruz de piedra, que se alzaba en la plaza de la iglesia. También derribaron y arrastraron otra cruz, que se erguía en la cumbre de El Calar". Los bancos de la iglesia fueron trasladados al centro obrero de la localidad ${ }^{147}$.

La consecuencia más llamativa de la iconoclastia desplegada por los anticlericales durante la Segunda República fue la destrucción de numerosos bienes historicos y artísticos de la Iglesia. Esto eclipsó los avances experimentados durante el gobierno republicano-socialista en el campo de la legislación protectora del patrimonio histórico, los cuales habían convertido a España en uno de los estados más avanzados del mundo en la materia ${ }^{148}$. El balance destructivo, aunque muy inferior al que se va a producir durante la Guerra Civil, es lo suficientemente dramático como para haber quedado como una duradera fuente de desprestigio para el régimen republicano ${ }^{149}$.

Es preciso señalar que la casi totalidad de los dirigentes cenetistas de Granada, y una parte importante de los ugetistas, socialistas y comunistas, eran obreros con una formación cultural autodidacta. Además, el $56 \%$ de la población de la provincia era analfabeta en 1930. "A la vista de estos

147 Testimonio del sacerdote Manuel Montes Moreno, ADG, 190-F/64.

148 Ordieres Diez, I., Historia de la restauración monumental en España (1835-1936), Madrid, Ministerio de Cultura, 1995, p. 41.

${ }_{149}$ La literatura propagandista de las derechas fue muy prolífica durante la Guerra Civil y la posguerra. En ella se repasaban los cuantiosos daños sufridos por el patrimonio histórico eclesiástico desde la proclamación de la República, fundiendo en un solo periodo el quinquenio republicano y la Guerra Civil. Granada se mostró particularmente activa en este tipo de literatura gracias a la existencia de un notable grupo de intelectuales y técnicos afectos a los sublevados: Prieto Moreno, Bermúdez Pareja, Emilio Orozco, Torres Molina y, el más destacado de todos, Antonio Gallego Burín. De ellos salieron obras magníficamente ilustradas como el Informe sobre las pérdidas y daños sufridos por el tesoro artístico de Granada de 1931 a 1936 e indicación de las obras salvadas de la destrucción marxista, Granada, Gobierno Militar, 1937, o La destrucción del tesoro artístico de España. Informe sobre la obra destructora del marxismo..., Granada, Imprenta $H^{\circ}$ Paulino Ventura, 1938. Trabajos de este tipo se hicieron también en otras provincias durante la guerra. Acabada ésta aún se publicaron folletos, que ya no pasaban de ser meros resúmenes de los trabajos publicados con anterioridad, como el Saqueo del tesoro religioso de España, Madrid, Oficina informativa española, 1948, cuyo objetivo era romper el aislamiento del régimen franquista demostrando al mundo occidental que Franco era un aliado útil frente a la amenaza soviética. Podía leerse en este tardio texto que si los republicanos volvieran «no tardarian mucho tiempo en encender otra vez inmensas hogueras donde abrasar las riquezas artísticas, históricas y culturales que permanecen intactas en las provincias en las que no pudieron saciar sus bárbaros instintos" (pp. 141 y 142). 
datos [escribe Calero Amor] puede afirmarse, sin el mínimo temor a caer en la demagogia, que la cultura era patrimonio de las clases acomodadas" ${ }^{150}$. No es de extrañar, pues, que para los elementos más radicales del movimiento obrero y jornalero quemar una iglesia fuera un acto tan revolucionario como atacar la sede de una organización derechista, un banco o un cuartel de la guardia civil, además de resultar mucho más fácil por haber muchos templos y carecer de protección. El mismo desprecio e iconoclastia mostró la derecha hacia las sedes obreras y la simbología izquierdista, con la particularidad de que estos bienes carecian de cualquier dimensión histórica o artística.

\section{CONCLUSIONES}

La monarquía y la Dictadura se habian configurado como escenarios ideales para la extensión de la influencia política y el poder económico de la Iglesia. El clero, intimamente vinculado a las clases propietarias, recibía un trato de favor de éstas y cuantiosas ayudas económicas y herencias. A la par, las organizaciones de la izquierda, contrarias al Estado confesional, eran mantenidas a raya por los diversos gobiernos. Un escenario tan favorable se derrumbó de la noche a la mañana con la proclamación de la Segunda República. La mayoría del clero quedó profundamente desconcertado y se limitó a aceptar el régimen formalmente, pero sin poder disimular su aborrecimiento. Dominado por el integrismo, consideraba los privilegios adquiridos durante la Restauración como derechos inalienables por cualquier poder terrenal y confundía el carácter de religión oficial del Estado con el de religión practicada por todos los españoles.

Cuestionar como se ha hecho tantas veces la legislación laica de la República no parece razonable si hacemos algo más que un superficial análisis político del quinquenio republicano. No se trata de determinar hasta qué punto el gobierno republicano-socialista fue torpe y desencadenó un enfrentamiento con la Iglesia, dado que el enfrentamiento era inevitable con una jerarquía eclesiástica que ya se sentía lesionada por la separación de la Iglesia y el Estado, y cuya alianza con la derecha venía dada de antemano. La República tenía la obligación de aceptar la realidad y adecuar la legislación a ella reconociendo que ya sólo una minoría de los españoles eran católicos practicantes y que eran muchos los ciudadanos que vivían absolutamente de espaldas al catolicismo. La República tenía

150 Calero Amor, op. cit., pp. 67 y 68. 
también el reto de intentar satisfacer las demandas de una izquierda que habia estado más de medio siglo apartada del poder político. No hacerlo era segar su base social y dar la razón a los sectores radicales de la izquierda que, como los anarcosindicalistas, aspiraban a la revolución.

Quien debia de hacer concesiones y mostrarse autocrítica con su trayectoria era la Iglesia, cuyos éxitos en crecimiento de propiedades, influencia política y aumento de efectivos, contrastaban con un extraordinario fracaso evangélico entre las clases populares. Quien debía mostrar interés en la estabilidad política era el clero, que tenía mucho que temer si se producía un vacío de poder y el movimiento obrero se adueñaba de las calles. Su política, fue, sin embargo, la de aglutinar a las derechas y polarizar la sociedad en un intento de crear las condiciones para una involución; primero la esperó de la derecha accidentalista liderada por Gil Robles, pero tras la victoria frentepopulista acabó por depositar sus esperanzas, como toda la derecha, en una intervención militar. Lo dramático del asunto es que la Iglesia renunciara a evangelizar mediante la labor pastoral a los trabajadores, y apostara por la represión y la purga purificadora, de todo lo cual ya hubo muestras en el "bienio negro". A los historiadores aficionados a exhibir los textos más o menos conciliadores de algunos obispos y emisarios del Vaticano, hay que enfrentarles la realidad de los hechos, que no es otra que unos párrocos apegados a las clases propietarias y unos periódicos católicos que, como el ldeal de Granada, destilaban día a día doctrina derechista.

Pero no se trata sólo de que la República tuviera la obligación moral de atender las demandas de quiénes tanto tiempo habían estado marginados del poder. Es que los de abajo, tanto el movimiento obrero organizado como los simpatizantes más o menos exaltados de la izquierda, exigian día a día la laicización de la sociedad, y lo hacían ejerciendo una presión que desbordaba la legalidad y amenazaba con imponer por la vía de los hechos lo que dilataba la lentitud parlamentaria ${ }^{151}$. La multitud de incidentes anticlericales recogidos en este trabajo corresponden sólo a dos diócesis que abarcan una provincia y parte de otra. Puede parecer que extrapolar esta realidad al resto del país es inadecuado. Sin embargo, la aproximación a las fuentes documentales demuestra que los enfrentamientos anticlericales eran extraordinariamente numerosos en todas las

151 Señala Manuel Delgado que superando el marco de las iniciativas legislativas: «Las turbas estaban ejecutando inconscientemente un plan lógico para resolver para siempre y del todo la secular "Cuestión religiosa» en España». DELGADO, M., La ira sagrada. Anticlericalismo, iconoclastia y antirritualismo en la España contemporánea, Barcelona, Editorial Humanidades, 1992, p. 20. 
provincias de Andalucía, en Madrid o en regiones tan distantes como Galicia y Asturias ${ }^{152}$. Las cifras sobre atentados anticlericales aportadas por Gil Robles el 16 de junio de 1936 han sido consideradas muchas veces como una exageración que pretendía desprestigiar a la República ${ }^{153}$. En realidad eran ciertas. El problema es que el diputado derechista y la Iglesia no extraían las consecuencias correctas, o sea, que para evitar los enfrentamientos era preciso desactivar el descontento mediante concesiones, y apostaban por una involución que necesariamente habría de ser violenta.

Ni siquiera la Guerra Civil y la cruenta posguerra, que supusieron el exterminio físico, el encarcelamiento o el exilio de toda una generación de militantes de izquierdas, permitieron que la Iglesia lograra la recristianización de los indiferentes y escépticos. Y es que la clave de la descristianización no estaba en el adoctrinamiento de las masas por los anarquistas y los marxistas, sino en la propia incapacidad de la Iglesia española de entonces para evangelizar a las clases populares. Para atraer al seno del catolicismo a los trabajadores era preciso preocuparse e identificarse con sus problemas, algo que no hizo el clero más allá de diversas obras de caridad y algunos sacerdotes aislados.

No obstante, la desafortunada alineación política del clero no basta para justificar la imprudencia de las organizaciones del movimiento obrero que alentaron los ataques anticlericales, caso de los anarcosindicalistas, o que no sancionaron a sus militantes implicados en ellos y convirtieron su respeto al catolicismo en meramente teórico, caso de los socialistas. La violencia anticlerical pudo ser útil a sus ejecutores porque contribuyó a destruir la fe de muchas personas y colaboró en la laicización de algunas dimensiones de la sociedad, pero también empujó al clero y a parte de los católicos hacia la derecha fascistizante en un peligroso proceso de polarización social. La expulsión de párrocos y los atentados iconoclastas confirmaban, a los ojos de clérigos y feligreses, la veracidad de los argumentos apocalípticos que desde los sectores más reaccionarios de la iglesia se dejaron oír contra la República desde el mismo momento de su proclamación.

\footnotetext{
152 Monografias provinciales sobre conflictividad agraria en provincias andaluzas demuestran exactamente el mismo tipo de incidentes anticlericales que hemos visto en las provincias de Granada y Almeria; véase por ejemplo PÉREZ YRUELA, La conflictividad campesina en la provincia de Córdoba (1931-1936), Madrid, Ministerio de Agricultura, 1979. Para buena parte de España, puede darse un detenido repaso, por ejemplo, al libro publicado en 1938 por Gallego Burin, La destrucción del tesoro artístico de España..., op. cit.

153 Estos datos eran: 170 iglesias destruidas por incendios y 251 intentos fallidos de quema, a la par que numerosos delitos de carácter diverso. JACKSON, op. cit., p. 187.
} 